\title{
The impact of human, social, and psychological capital on academic spin-off internationalization
}

\author{
Mariluz Fernández-Alles ${ }^{1}\left[\right.$ ] Dara Hernández-Roque ${ }^{1}$. \\ Mercedes Villanueva-Flores ${ }^{1}\left[\right.$. Mirta Díaz-Fernández ${ }^{2} \odot$
}

Accepted: 10 February 2022 / Published online: 1 March 2022

(c) The Author(s) 2022

\begin{abstract}
Academic spin-offs (ASOs) are companies with a strong international vocation for two main reasons: first, they market their products and services in global market niches to profit from their high investment in R\&D, characteristic of the sectors in which ASOs operate; and second, as a consequence of the international training and experience and of the international networks that the founding academic entrepreneurs of these companies tend to enjoy, derived from their scientific activity. Despite this natural tendency to internationalize, ASOs and specifically the founding academic entrepreneurs of these companies present certain difficulties in accessing resources for internationalization and in achieving credibility in foreign markets due to their university origins. Based on the resource-based view (RBV), and network theory (NT), this work proposes that the human capital, the social capital, and the psychological capital of the academic entrepreneur could compensate for these obstacles, providing key resources for the internationalization of their companies. The results contribute to the RBV, NT, and academic entrepreneurship and internationalization literature since they show that human capital, in terms of the international experience and training of the academic entrepreneur, their networks of relationships with international academic agents, and their psychological capital, are all antecedents of the internationalization of ASOs. However, the networks of academic entrepreneur relationships with international market agents appear to be irrelevant in the process of international expansion of ASOs.
\end{abstract}

\section{Resumen}

Las spin-offs académicas (SOA) son empresas con una fuerte vocación internacional por dos razones principales. Primero, porque comercializan sus productos y servicios en nichos de mercado globales para beneficiarse de su alta inversión en I+D, característica de los sectores a los que pertenecen las SOA. Segundo, como consecuencia

Mariluz Fernández-Alles

mariluz.fernandez@uca.es

Extended author information available on the last page of the article 
de la formación y experiencia internacional y de las redes internacionales, de las que suelen disfrutar los emprendedores académicos fundadores de estas empresas, derivadas de su actividad científica. A pesar de esta tendencia natural a la internacionalización, las SOA y específicamente los emprendedores académicos fundadores de estas empresas, presentan ciertas dificultades para acceder a recursos para la internacionalización y para lograr credibilidad en los mercados externos, debido a sus orígenes universitarios. Partiendo de la visión basada en los recursos (VBR) y la teoría de redes (TR), este trabajo propone que el capital humano, el capital social y el capital psicológico del emprendedor académico podrían compensar estos obstáculos proporcionando recursos claves para la internacionalización de sus empresas. Los resultados contribuyen a la VBR y TR y a la literatura de emprendimiento académico e internacionalización, ya que muestran que el capital humano, en términos de la experiencia internacional y formación internacional del emprendedor académico, sus redes con agentes académicos internacionales, y su capital psicológico influyen en la internacionalización de las SOA. Sin embargo, las redes de los emprendedores académicos con los agentes del mercado internacionales parecen ser irrelevantes en el proceso de expansión internacional de las SOA.

Keywords Academic entrepreneur · Internationalization · Academic spin-offs · Human capital · Social capital · Psychological capital · Resource-based view · Network theory

\section{Summary highlights}

Contributions: The article contributes to the development and greater understanding of the literature on academic entrepreneurship and internationalization of ASOs, delving into the profile of the academic entrepreneur (their human, social, and psychological capital) and its influence on the internationalization of ASOs. In addition, the psychological capital of the academic entrepreneur is studied, which, to date, has not been analyzed in the literature on academic entrepreneurship.

Research Questions and Purpose. The profile of the academic entrepreneur could influence internationalization and contribute to overcoming the obstacles and barriers faced by ASOs. The objective of this work is to analyze the influence of the three capitals of the academic entrepreneur, human, social (academic and market network), and psychological capital, on the internationalization of ASOs.

Basic Research Methodology. Our hypotheses have been tested on a sample of 173 ASOs of Spanish universities, using Structural Equation Models (SEM).

Results/Findings. The results show that the human, social, and psychological capital of the academic entrepreneur have a positive effect on the internationalization of ASOs. Although, with respect to social capital, the international academic network is positively related to internationalization; however, the international market network is not positively related to the internationalization of ASOs. 
Limitations. One limitation is the method of collecting the network data, as they are dynamic and changing. Another limitation is that our sample draws from Spanish ASOs, and therefore, the results achieved could differ for samples from other countries. Finally, only the main founder of the ASO was questioned in the survey.

Theoretical Implications and Recommendations. Few studies that integrate RBV and NT are found in the literature on academic entrepreneurship and internationalization. This integration allows us to explain how academic entrepreneurs, through their human, social, and psychological capital, internationalize their companies as a result of the resources that these capitals provide. In addition, we contribute to NT by analyzing the peculiarities of academic entrepreneurs' networks of relationships which generate social capital, which promotes internationalization. Finally, the psychological capital of the academic entrepreneur, which has not been addressed in this field, is added and studied together with human and social capital.

Practical Implications and Recommendations. To achieve the internationalization of ASOs, which constitutes one of the most important transfer performances within the third mission of universities, academic institutions should help academic entrepreneurs, by means of advice or training. They should also encourage the establishment of collaboration networks, with agents, in the international university context. Academic policies should carry out psychological capital interventions, to develop academic entrepreneurs' psychological capital. Consequently, training programs could reinforce their psychological capital.

Future Research Directions. We recommend that the proposed model be validated, using samples from other countries, to establish comparisons. In addition, new studies could be carried out to analyze the impact of human, social, and psychological capital.

\section{Introduction}

The transfer of technology from the university to society was an emerging issue when the Bayh-Dole Act of 1980 was enacted, solving the problem of government ownership of intellectual property rights, over state-funded research. The law codified and legitimized a set of practices and relationships, which allowed the research participants to own these discoveries, and commercially exploit them, encouraging the transfer of knowledge from the university to society (Etzkowitz and Zhou 2017). In this context, the triple helix model originated. The university changes its role; it becomes an equal partner in a triple relationship, between government, industry, and the university (Etzkowitz and Leydesdorff 2000; Etzkowitz 2003). Due to the triple helix model, the third mission of knowledge transfer is incorporated into the universities, (Etzkowitz and Leydesdorff 2000; Algieri et al. 2013), in addition to the teaching and research functions. In this third mission, the university is positioned as an "entrepreneurial university," and this term was coined by Ezkowitz, in 1998, and places universities as key institutions for the transmission of knowledge and 
promoting innovation. For this transmission, or third mission, the university implements mechanisms, such as patents, licenses, or the creation of academic spin-offs (ASOs) (Etzkowitz 2003). The ASO is a "new company created to commercially exploit some knowledge, technology or research results, developed within a university" (Pirnay et al. 2003: 356). Moreover, ASOs are most prominent in promoting knowledge transfer and the commercial perspective of university research (O'Shea et al. 2008; Conceição et al. 2012; Visintin and Pittino 2014). ASOs contribute to the economic and social growth of the country, through their impact on job creation, innovation (Fernández-Alles and Ramos-Rodríguez 2021), and wealth creation (Roberts and Malone 1996).

ASOs are companies with a strong international vocation for two reasons. On the one hand, ASOs are companies that usually compete in sectors intensive in advanced technologies, with a major investment in $\mathrm{R} \& \mathrm{D}$, making their expansion in international markets a commercial priority in order to recover those high investments and swiftly generate results (Evers et al. 2016). For this reason, these companies target global market niches for the commercialization of their products and services (Evers et al. 2016; Civera et al. 2019). On the other hand, academic entrepreneurs often have international training and experience, and a network of international relationships derived from their research and scientific activity, which could contribute towards the rapid internationalization of these companies (Björnali and Aspelund 2012; Van Geenhuizen et al. 2015; Bialek-Jaworska and Gabryelczyk 2016; Evers et al. 2016; Civera et al. 2019, 2020). However, the profile of the founding academic entrepreneur of the ASO presents certain peculiarities related to his/her academic origins which could hinder the internationalization process. In this respect, the literature highlights the lack of global vision of these entrepreneurs, the lack of management and marketing skills, the limited network of relationships with market agents, and that the signs of visibility and credibility that these entrepreneurs send to the market are based on academic and non-market indicators that are not easily understood by resource providers (Vohora et al. 2004; Moray and Clarysse 2005; Mustar et al. 2006; Wright et al. 2006; Saetre et al. 2009; Van Geenhuizen and Soetanto 2009; Fernández-Alles et al. 2015; Yang et al. 2020). This leads to difficulties in accessing resources critical for their internationalization. Therefore, the meaning of the incidence of the profile of the academic entrepreneur in the ASO internationalization process, remains controversial, and justifies focusing this work on the figure of the academic entrepreneur, and their three capitals.

Previous research, such as that of Beechler and Javidan (2007) and Dauth and Tomczak (2016), considers three capitals as keys for the management team to obtain a global mindset that would benefit the internationalization. International human capital of entrepreneurs, based on their international experience and training, would lead to obtaining critical knowledge resources for internationalization. The first of these are as follows: the knowledge of clients and competitors in foreign markets; institutional knowledge, knowledge of foreign government institutions; and knowledge of the internationalization process itself (Gajowiak 2013). This capital would help them build and manage global alliances, agreements, and value networks; resolve tensions between local and global requirements; and manage complex multicultural issues in order to become familiar with global business (Dauth and 
Tomczak 2016). In second place, the networks of relationships of the entrepreneur would provide social capital and therefore access to decisive resources for the international expansion of companies. This capital would also allow the entrepreneur to develop the skills necessary to motivate and connect with people from different cultures (Dauth and Tomczak 2016). Finally, psychological capital could compensate for the lack of resources for internationalization (Kiss et al. 2012), since it would lead the entrepreneur to have certain personal characteristics that would increase the intention and decision to internationalize (Hambrick and Mason 1984; Sapienza et al. 2006; Maitland and Sammartino 2015; Onkelinx et al. 2016; Lai et al. 2017; Anwar et al. 2018; Wach and Głodowska 2021), and therefore, adapt and cope with other cultures, as well as to face the challenges and risks of internationalization (Dauth and Tomczak 2016).

In the context of SOA, previous research has focused on the study of human and social capital of the entrepreneur (Taheri and Van Geenhuizen 2011; Bialek-Jaworska and Gabryelczyk 2016). However, work focused on the impact of the entrepreneur's psychological capital on internationalization remains scarce (Beechler and Javidan 2007; Senik et al. 2014; Baum et al. 2015). In addition, there are no studies that analyze the psychological capital of academic entrepreneurship relating it to the internationalization of ASOs. In fact, there are no works that focus on the three capitals together, in the case of academic entrepreneurship, and in this respect, it would be useful to analyze the international human capital, social capital, and psychological capital of the academic entrepreneur.

With this background, and based on resource-based view and network theory, the objective of this work is to analyze the impact of the human, social, and psychological capital of the academic entrepreneur, on the internationalization of ASOs. The methodology used is based on Structural Equation Models that have been carried out, with the data collected through the questionnaire sent to the founders of the Spanish ASOs.

The main contribution of this work is that our results contribute to the literature on academic entrepreneurship and internationalization, providing evidence of the significant role that the international human capital (experience and training) of academic entrepreneurs, their network of international academic relationships, and the psychological characteristics of the academic entrepreneur exert on the internationalization of ASOs.

Subsequent to this introduction, the main obstacles related to the academic entrepreneur that ASOs face for their internationalization are analyzed. In the following section, the three dimensions of the entrepreneur that could foster internationalization are addressed, and the hypotheses established, followed by the methodology and the results. Finally, the discussions, limitations, and future lines of research are presented.

\section{Obstacles of the academic entrepreneurs to ASO internationalization}

Based on RBV and on the literature on internationalization, three barriers or resources deficiencies could limit the international expansion of companies: those related to human and financial capital; information and network barriers; and legal 
and procedural barriers (Van Geenhuizen et al. 2015). In the context of ASOs, and specifically in relation to academic entrepreneurs, we encounter four major obstacles related to their profile, their network of relationships, their signs of visibility, and their identity that could threaten the expansion of ASOs in international markets. Specifically, these obstacles could hinder access to resources that internationalization requires (Yeoh 2004; Björnali and Aspelund 2012). Examples include the following: commercial resources, to establish new marketing and sales channels; information resources, to ascertain the markets to address; and resources of credibility in the new market, to gain the trust of the suppliers of resources critical for the international expansion of these companies.

In relation to the profile of the academic entrepreneur, ASOs are companies founded by academics who have notable training and scientific experiences as a result of their research profile, although they often lack the managerial, financial, commercial, and entrepreneurial skills and resources necessary for business management (Franklin et al. 2001; Vohora et al. 2004; Wright et al. 2006; Van Geenhuizen and Soetanto 2009; De Cleyn et al. 2011; Hayter 2015; Parente et al. 2015; Mikhailova and Olsen 2016). Parente et al. (2015: 557) state that "academic spinoffs are a direct expression of a non-commercial, scarcely business-oriented environment, and are promoted by subjects with a scientific background and with a mindset, competencies, relations, and behavior that are very often completely different from those required in business contexts."

These shortcomings hinder not only the creation and development of ASOs themselves (Fernández-Alles et al. 2015), but also their internationalization. With these initial resources deficiencies, academic entrepreneurs may find it difficult to recognize and take advantage of international opportunities; to develop business plans with an attractive international dimension for potential investors (Wright et al. 2006; Munari and Toschi 2011); to overcome the strong uncertainty of the market, its clients, and marketing channels that internationalization of business involves (Shane 2004); and, for the development of key functions, to operate in markets other than the domestic market, such as negotiation, planning, decision-making, organization, and communication (Shane 2003). Furthermore, academic entrepreneurs have no previous track record related to undertaking business in specific markets (Vohora et al. 2004), and since reputation tends to be built on past actions, the construction of legitimacy in foreign markets is problematic for these companies whose promoters lack previous references. Therefore, both the deficit presented in management competencies and experiences, and the absence of a previous track record, could seriously hinder the assessments of their reliability made by suppliers of resources critical to internationalization.

Second, academic entrepreneurs often maintain strong links to the university context, and develop close relationships with university agents, such as departments, other colleagues, Technology Transfer Offices (TTOs), university incubators, and other academic agents, although they tend to lack a network of relationships with market agents, such as customers, suppliers, competitors, and the government (Clarysse et al. 2005; Mosey and Wright 2007; Rasmussen 2011; Karlsson and Wigren 2012; Fernández-Alles et al. 2015; Mikhailova and Olsen 2016). Relationships with these academic actors do not favor the creation of an initial stock of credibility in 
the markets and of their own corporate identity with clients, suppliers, and investors (Vohora et al. 2004; Gübeli and Doloreux 2005), which hinders access to both national and foreign markets (Wright et al. 2004).

The third obstacle is related to the signs of visibility that academic entrepreneurs send to the foreign market to build ASO legitimacy. Academic entrepreneurs tend to base their credibility on quality indicators of their research performance and not of their entrepreneurial performance. Although these indicators of the quality of research are international in scope, such as their top ranked publications or international patents, they are often not understood by market agents, which hinders their credibility for access to the critical resources necessary for internationalization (Di Gregorio and Shane 2003; Ambos et al. 2008; Karlsson and Wigren 2010; Audretsch and Aldridge 2012; Pettersen and Tobiassen 2012).

Finally, academic entrepreneurs often have a dual identity that can threaten the construction of their credibility in foreign markets. On the one hand, academics usually have an academic identity (Sahaym 2013), oriented to the long-term, and with the aim of publishing high-quality articles. On the other hand, they also possess an entrepreneurial identity, where short-term profitability clash with the objectives of the aforementioned academic identity (Zou et al. 2008).

Despite these obstacles, the figure of the academic entrepreneur possesses certain characteristics inherent in his/her scientific activity and personal traits that may foster the internationalization of the ASO and these will be addressed in the following section.

\section{Dimensions of the academic entrepreneur that promote ASO internationalization: Human, social, and psychological capital}

Beechler and Javidan (2007) consider three key dimensions in which the global mindset of the management team can appear: human, social, and psychological capital (Dauth and Tomczak 2016). Most of the literature on internationalization focuses on the analysis of the human and social capital of the entrepreneur or manager (Weerawardena et al. 2007; Evers and O'Gorman 2011; Senik et al. 2014; Baum et al. 2015), with the psychological capital of the entrepreneur as the object of least study. Evers and O'Gorman (2011) argue that internationalization is strongly influenced by the prior knowledge of entrepreneurs and by their previous network of social and business relationships. Weerawardena et al. (2007) also point to previous international experience, training abroad, and contacts as antecedents of the search for international opportunities. Senik et al. (2014) and Baum et al. (2015) highlight the importance of the personal characteristics of managers and relationship networks, among other factors, for internationalization. In the context of ASO internationalization, Bialek-Jaworska and Gabryelczyk (2016) have indicated how international experience and training, and the networks of previous international relationships of academic entrepreneurs, could compensate for the lack of training and experience in business management in international markets. Experience and networks could even offset the liabilities of newness and foreignness (Andersson and Berggren 2016). Both aspects, experience and international networks, are also 
analyzed by Taheri and Van Geenhuizen (2011). In the next section, we analyze the arguments that lead us to pose hypotheses focused on analyzing the impact of each of the three types of capital on the internationalization of ASOs, and for this, we rely on network theory and resource-based view.

According to the network theory of internationalization, companies immersed in a network of relationships have a competitive advantage which allows them to enter foreign markets more easily (Johanson and Mattson 1985; 1988; Gajowiak 2013). Similarly, in the resource-based vision, which constitutes one of the most commonly used theoretical frameworks in internationalization research (Peng 2001; Mohr and Batsakis 2014; Kazlauskaitė et al. 2015; Sánchez et al. 2015; Pigatto et al. 2019), the companies' possession of specific strategic resources has effects on the internationalization and speed of internationalization (Mohr and Batsakis 2014). Based on the resource-based view, the human, social, and psychological capital of the entrepreneur can be considered valuable resources that are rare assets and difficult to imitate, and, therefore, a source of sustainable competitive advantage (Luthans et al. 2004; Luthans et al. 2007a).

\section{The impact of international human capital in the internationalization of ASOs}

Human capital comprises many elements, including experience (financial, sector, international, and leadership), educational level, know-how, and training (Civera et al. 2020). In the entrepreneurship literature, a group of variables related to the entrepreneur's profile has been identified, including elements such as their training and educational level, which can be interpreted as the entrepreneur's ability (Nielsen 2015). The human capital of the founder or manager has been considered a valuable resource for internationalization (Kazlauskaitè et al. 2015). For Civera et al. (2020), international human capital allows for a more holistic perspective, different points of view, flexibility, intrinsic dynamism, and open-mindedness, which would lead them to become more acutely aware of the advantages of internationalization. For the internationalization of companies, international human capital is important, as it provides a key resource of international market knowledge. This international human capital can be derived from work experience resulting from international mobility, education, or training abroad, and even from vacation time (Sambharya 1996; Carpenter et al. 2003; Björnali and Aspelund 2012). Following Kazlauskaite et al. (2015), international market knowledge "is usually gained through the entrepreneur's international experience, in the form of education and work experience abroad" (p:56).

International experience, according to Johnson (2004), Lukason et al. (2021), and Wach and Głodowska (2021), is responsible for the early internationalization of hightech start-ups. Some authors explain how the desire on the part of entrepreneurs to capitalize on their resources, such as international experience, can provide a reason for the internationalization of their companies (Bloodgood et al. 1996; Lukason et al. 2021).

International experience constitutes a necessity in the global business world and one of the most influential characteristics of managers or entrepreneurs in the 
internationalization of companies (Oviatt and McDougall 1995, 1997; Bloodgood et al. 1996; Sambharya 1996; Tihanyi et al. 2000; Athanassiou and Nigh 2002; Carpenter et al. 2003; McDougall et al. 2003; Herrmann and Datta 2005; Rivas et al. 2009; Nielsen 2010; Baum et al. 2015; Andersson and Berggren 2016; Dauth and Tomczak 2016; Volonté and Gantenbein 2016; Lukason et al. 2021).

Herrmann and Datta (2005) establish that international experience endows the manager with a personality and perceptions that positively influence international orientation. International experience therefore leads to a global mindset that helps entrepreneurs lose their fear of entering new markets (Laurell et al. 2013). Likewise, Nielsen (2010:188) points out that "international experience has an influence on managers' perceptions and personalities and contributes to higher international orientation of top executives," and hence, background and guidance would explain internationalization. International experience allows situations to be interpreted in a different way, which in turn affects the decisions that are made, since international experience reduces contextual uncertainty and dependency (Rivas et al. 2009). For these authors, having this experience leads them to better manage uncertainty and complexity, and to gain a lower perception of risk, which in turn promotes a more aggressive commitment to the resources that internationalization requires. Therefore, knowledge, mentality, and security are a consequence of this experience. Carpenter et al. (2003) communicate along the same lines when pointing out the relationship between international experience and risk, as do Leonidou and Katsikeas (1996) in relation to uncertainty. International experience makes it possible to reduce the complexity of the information available, to attain a greater capacity to make complex decisions, such as that involved in entering a foreign market, to view internationalization activity as less risky, to improve decision-making regarding foreign investments, and to increase alternatives. It also enables better judgments to be made regarding opportunities to enter foreign markets and to select more modes of entry into foreign markets: in short, to assess all the elements involved in the process of international expansion, to improve the negotiation process with partners or local suppliers, and to gain higher cultural and institutional awareness (Athanassiou and Nigh 2002; Nielsen 2010). According to Sambharya (1996), the international experience constitutes a proxy for the reduction of uncertainty and is a surrogate for the accumulation of cultural knowledge (Civera et al. 2020). With this background, the accumulated experiential knowledge constitutes the basis for the internationalization of companies, since the accumulated experience of the country, its market, and its institutions results in the better knowledge and understanding of international markets (Nielsen 2010; Kamakura et al. 2012).

According to these authors (Beechler and Javidan 2007; Dauth and Tomczak 2016; Wach and Głodowska 2021), international experience and training allows them to formulate international strategies, develop transnational skills, possess a global perspective, gain a greater capacity for relations with foreign companies, and enjoy greater local responsibility. For McDougall et al. (2003) and Baum et al. (2015), international experience may lead to the identification of opportunities, the knowledge of the market, and the construction of networks of relationships, all of which are aspects that promote internationalization by reducing the liabilities of foreignness. Therefore, the accumulated international experience helps managers 
explore geographically more distant markets (Nielsen 2010). For Bruneel et al. (2018), international experience leads to greater knowledge and the acquisition of international skills.

The educational level of their founders can be important in the speed of internationalization of ASOs, and in the case of academic entrepreneurs, they are usually highly qualified (Acedo and Casillas 2007; Pinkwart and Proksch 2014; Teixeira and Coimbra 2014). Specifically, with respect to international training, Lamotte and Colovic (2015) and Dauth and Tomczak (2016) state that it influences the internationalization of the company. The knowledge gained from international training can enhance the individuals' understanding of customs and habits in foreign markets (Yeung and Ready 1995; Carpenter et al. 2001). This leads them to a greater understanding of foreign markets and this insight leads them to internationalize (Dauth and Tomczak 2016).

Both international experience and international training allow exposure to foreign markets. This exposure, according to Kuemmerle (2002), often gives rise to the idea of an international company. According to Oviatt and McDougall (1995), contact with international markets enables the understanding of the culture of the country where it operates, promotes communication, and the reduction of cultural conflicts.

In the case of ASOs, several studies have analyzed the impact of the international experience of academic entrepreneurs on their internationalization (Bialek-Jaworska and Gabryelczyk 2016), stemming from the international dimension of the relationships that their scientific activity implies, and from the international mobility and training abroad derived from the development of their academic and research activity. In this respect, the scientific and research activity of academic entrepreneurs is usually multicultural and based on international relations, whether it be with other academics, foreign universities, or international research centers (Bialek-Jaworska and Gabryelczyk 2016; Civera et al. 2020), which would entail a positive impact on internationalization. Furthermore, ASO promoter teams usually receive research funding through international grants, scholarships, and research programs, which often involve establishing international collaboration and stays abroad.

This mobility is a prerequisite in the application for these financial grants, and it provides academics with international experience and international networks that would accelerate the process of internationalization of ASOs, due to the effects of this experience and networks in the recognition of entrepreneurial opportunities, in the development of skills, in greater human capital and innovative capacity, and in the greater creativity that new ideas and perspectives would provide (Van Geenhuizen et al. 2015; Bialek-Jaworska and Gabryelczyk 2016; Civera et al. 2020). Furthermore, many of these entrepreneurs carry out international transfer activities, such as patents, which give them credibility in foreign markets, thereby enhancing their entry into international markets when they decide to commercially use their knowledge through ASOs (Bialek-Jaworska and Gabryelczyk 2016). In this respect, Civera et al. (2020) point out how scientists with more international experience enjoy higher productivity in terms of publications and patents, which would increase their credibility in international markets. Academics often participate in stays abroad that are necessary for their future university accreditation processes, which endow them with a better knowledge of foreign markets, as well as a network of international 
relationships. Therefore, regardless of the origin of this international experience, the consequence is that their academic activity endows them with a network of international relationships, a knowledge of foreign markets, and a global perspective that would create credibility in foreign markets, thereby promoting internationalization (Björnali and Aspelund 2012; Bialek-Jaworska and Gabryelczyk 2016; Evers et al. 2016; Civera et al. 2019). Finally, with respect to international training, the researchers promoting these companies have usually received academic training in the international context, whether it be via a master's or a doctorate, which has allowed them to acquire and accumulate international experience that, without a doubt, would increase the potential of international expansion of their companies (Fernández-Alles and Ramos-Rodríguez 2021). In this respect, prior international training could be a sign of visibility and greater credibility in international markets (Civera et al. 2019).

From the arguments put forward, we deduce that the academic entrepreneur's international human capital, through international experience and training abroad (courses, masters, even research stays, etc.), could provide important resources to build a global mindset, generate a greater understanding and knowledge of global markets, and reduce uncertainty and fear of expanding into new international markets. So, we propose the hypothesis:

H1. The international human capital of the academic entrepreneur has a positive impact on the internationalization of the ASO

\section{The impact of international social capital in the internationalization of ASOs}

For Hilmersson (2014), relationship networks constitute another key type of experiential knowledge for internationalization. Internationalization is defined as a process of building business networks in international markets (Ruzzier et al. 2006). The impact of international human capital on international social capital is widely supported in the literature (Oviatt and McDougall 1995; Laurell et al. 2013; Civera et al. 2020). On many occasions, confidence arises from international experience to build networks of relationships for business (Oviatt and McDougall 1995), while international mobility, whether for study purposes or other types of travel, may also cause these international networks to emerge that can facilitate the creation of new key networks for internationalization (Laurell et al. 2013; Civera et al. 2020).

Research on the impact of relationship networks on the internationalization of companies has appeared in the literature on the internationalization of companies, to such a degree that since the studies by Johanson and Mattson $(1985,1988)$ which describe markets as network systems, thus emphasizing that internationalization processes are influenced by networks between companies. This gave rise to the so-called network theory of internationalization. Coviello and Munro (1995, 1997) argue that companies immersed in a network of relationships have a competitive advantage, which facilitates their expansion abroad. Certain authors have even argued that the advantages of owning this network of relationships could offset the 
lack of previous experience in a specific foreign market (Gajowiak 2013), by overcoming the liabilities of newness, smallness, and foreignness with the resources that these networks provide (Laurell et al. 2017; Peces Prieto and Trillo Holgado 2019). In this way, the density and size of the network would influence internationalization (Baum et al. 2015).

No consensus can be encountered in the literature on academic entrepreneurship nor in that on internationalization regarding the way in which the networks of relationships of companies are classified. Andersson et al. (2013) distinguish between local and international networks. Along these same lines, Laurell et al. (2017) highlight that not only are international relationships key to the internationalization process, but local networks are also essential, such as with universities and hospitals. Laurell et al. (2013), Mikhailova and Olsen (2016), and Franco-Leal et al. (2020) distinguish between academic, institutional, and social business relationship networks. Others, such as Coviello and Munro (1995), Rasmussan et al. (2001), Shirokova and McDougall-Covin (2012), Laurell et al. (2017), and Sekliuckiene (2017), distinguish between formal (business-related) relationships and informal or social (family and friends) relationships. Civera et al. (2020) include university colleagues among the latter category, while Senik et al. (2014) identify networks with government institutions, business partners, and personal relationships as the key networks for the internationalization of small and medium-sized companies. Wright and Dana (2003) and O'Gorman and Evers (2011) present another typology of networks, and categorize them into horizontal networks (such as trade associations, competitors, joint action groups, industry cluster EPOs, consultants, and government agencies), vertical networks (clients, buyers, and suppliers), and trans-industry networks (other agents that participate in the value chain). Ratajczak-Mrozek (2017) distinguishes between primary relationships (suppliers and buyers) and secondary relationships that include technology, materials, knowledge, trust, and Marketing-based relationships. Finally, Fernández-Alles et al. (2015), in the field of ASOs, distinguish between networks of academic and market relationships.

Regardless of the classification criteria adopted, the literature has specifically indicated the set role that certain agents play in the internationalization process. In particular, research on the impact of vertical relationship networks on internationalization is the most prolific. In the field of internationalization, the critical agents are market agents related to commercial resources, financial resources, and to networks of personal relationships (Fernhaber et al. 2009; Peces Prieto and Trillo Holgado 2019). Regarding commercial agents, those in sales stand out, since this interaction allows a better understanding of the context and of the clients, the preparation and validation of the offer, and the construction of long-term relationships (Lehto 2015). Roberts and Senturia (1996) establish that relationships with international clients and distributors could constitute an important boost for internationalization.

O'Gorman and Evers (2011) and Liu et al. (2021) expand this range and highlight clients, suppliers, and distributors, who provide important resources for internationalization. These authors also point to an intermediary agent, such as an export promotion organization, as the key to internationalization, since it enables opportunities and foreign clients to be identified, these clients to be accessed, knowledge of the 
foreign market to be provided, and resources to be supplied for the development of the export capacity of the company. Oviatt and McDougall (1995) highlight financial agents, customers, and suppliers. Andersson and Berggren (2016) deduce the relevant role of distributors and agents.

Holmlund and Kock (1998) point to the agents and the company's sales team. According to Zahra et al. (2003), technological networks influence the speed and degree of internationalization. On the other hand, in relation to financial agents, Fernhaber et al. (2009) indicate the networks of relationships with internationally renowned venture capital companies, or with companies with international experience as promoters of the internationalization of the companies they finance, by the reputation that these relationships confer upon them. Finally, the support of public or private institutions (for example as part of an incubation program with financial and technological support), research with partners, and investor relations (such as venture capital companies) are defined by these authors as signs of openings into foreign markets (Civera et al. 2019).

There are numerous studies that affirm that relationship networks positively impact the mode, speed, and scope of internationalization (Coviello and Munro 1995; Oviatt and McDougall 1995; Holmlund and Kock 1998; Coviello 2006; Coviello and Cox 2006; Weerawardena et al. 2007; Gajowiak 2013; Laurell et al. 2013; Senik et al. 2014; Baum et al. 2015; Mikhailova and Olsen 2016; Sekliuckiene 2017; Wach and Głodowska 2021). It is generally accepted in previous research that international networks stimulate connections with international society by supporting global development (Mikhailova and Olsen 2016), which affects the dynamics of various aspects of international entrepreneurship (Leite et al. 2016; Liu et al. 2021). Networks could provide the resources necessary for internationalization, as well as the credibility and legitimacy, which would facilitate the development of new capacities for low-risk international expansion (Zaheer and Mosakowski 1997; Wright et al. 2007; Laurell et al. 2017). In addition, networking is even more important for small companies, making it easier for them to obtain the necessary resources for internationalization (Dana 2001). Of all the resources that relationship networks can provide, Coviello and Munro (1995) and Liu et al. (2021) concluded the importance of commercial resources, such as market studies, customer services, and access to distribution channels and credibility resources, which enable the selection of new markets and entry therein.

In the same way as international human capital, networks reduce uncertainty and risk, by facilitating access to markets and providing financial support and support for market learning (Baum et al. 2015). More specifically, the literature argues that international networks enable the following: (i) information and contacts to be obtained, thereby reducing the risks perceived by the entrepreneur (Oviatt and McDougall 1994, 1995; 2007; Ellis and Pecotich 2001; Zahra and George 2002a, Zahra and George 2002b; Welch and Welch 2004; Herrmann and Datta 2005; Loane and Bell 2006; Peiris et al. 2012; Shirokova and McDougall-Covin 2012; Leite et al. 2016; Bai et al. 2021); (ii) the identification of foreign partners (Shirokova and McDougall-Covin 2012); (iii) the acquisition of tacit knowledge regarding international business practices (Sharma and Blomstermo 2003; Haahti et al. 2005; Bai et al. 2021), advice, and experiential and assistance learning in the negotiation 
process (Oviatt and McDougall 1995; Zhou et al. 2007; Bai et al. 2021), and commercial and political knowledge, which is the key for both entrepreneurs and companies to be informed of aspects related to internationalization (Welch and Welch 2004; Schweizer et al. 2010; Bai et al. 2021; Liu et al. 2021); (iv) the formation of an international vision and an opening for management (Yeoh 2004); (v) reputation, trust, and commitment to be attained in order to exploit international opportunities (Oviatt and McDougall 1995; Zahra and George 2002a, Zahra and George 2002b; Zhou et al. 2007; Shirokova and McDougall-Covin 2012; Sekliuckiene 2017; Bai et al. 2021). According to Turcan (2013), the first way to achieve external legitimacy in international markets is to establish agreements with partners or alliances with relevant organizations that would allow them to enter international markets (Vapola 2011); (vi) the development of R\&D activities (Zhou et al. 2007; Bai et al. 2021), since networks constitute a portal for technology and innovation; (vii) access and development of competitive resources (Oviatt and McDougall 1994; Coviello and Cox 2006; Amal et al. 2008); (viii) the recognition of international opportunities that overcome the disadvantages of being new and foreign (Coviello and Cox 2006); and (ix) the development of social capital that promotes the ability to expand abroad (Shirokova and McDougall-Covin 2012).

In the case of academic entrepreneurship, Laurell et al. (2017) point out that, in early stages, the relationships of companies are those of the entrepreneur at the individual level, and hence, these networks are usually personal. However, the academic entrepreneur presents a particular case. As a consequence of both their training abroad and the multicultural nature of their scientific and research activity and their international mobility, the founding academic entrepreneurs of these companies are usually endowed with a network of collaboration in their international research (Civera et al. 2020; Fitzgerald et al. 2021), which could encourage the internationalization of these companies (Björnali and Aspelund 2012; Evers et al. 2016). Despite the limited network of relationships that these companies have with market agents (Fernández-Alles et al. 2015), collaboration with foreign universities and with other international research centers for R\&D could undoubtedly promote the development of strategic alliances, access to distribution channels, the building of customer relationships, the search for solutions in the development of new products, and "cash in" investments in R\&D, intellectual property, and know-how, all factors that facilitate the internationalization of ASOs (Bialek-Jaworska and Gabryelczyk 2016). The reputation of the universities of origin, of the research centers or institutions with which they collaborate in their publications, and even of the entities that finance ASO research, would act as reputational networks and symbolic signals, increasing the credibility of ASOs both in national and international markets (Civera et al. 2019).

On the other hand, academic entrepreneurs maintain relationships with other foreign scientists, who are born or trained in other countries, derived from their scientific activity that would contribute positively to the internationalization of their companies (Krabel et al. 2012; Libaers and Wang 2012; Van Geenhuizen et al. 2015). These relationships exist, first, because foreign scientists can recognize entrepreneurial opportunities that do not exist in their home countries (Krabel et al. 2012), and second, because foreign academics are better at attracting research resources 
than exploiting their inventions (Libaers and Wang 2012). In this vein, Andersson and Berggren (2016) declare that the researchers themselves attend international conferences and fairs that allow them to support and promote products internationally in global markets.

Based on these arguments, we suggest that the social capital of the academic entrepreneur could be related to internationalization. Therefore, the social capital of academic entrepreneurs, academic and market networks, could be key to accessing and entering new international markets. So we propose the following hypothesis and sub-hypotheses:

H2. The international social capital of the academic entrepreneur has a positive impact on the internationalization of the ASO

$\mathrm{H} 2$.1. The international academic networks of the academic entrepreneur have a positive impact on the internationalization of the ASO

H2.2. The international market networks of the academic entrepreneur have a positive impact on the internationalization of the ASO

\section{The impact of psychological capital in the internationalization of ASOs}

Psychological capital originates from a stream of positive psychology that focuses on studying individuals' positive strengths and on how to develop and nurture said strengths (Seligman and Csikszentmihalyi 2000; Peterson 2006). Positive Organizational Behavior arises from positive psychology and is defined as the study and application of the psychological strengths and capacities of positively oriented people, which can be effectively measured, developed, and managed for the optimization of human management in the context of employment and applied to organizations and human resource management (Luthans et al. 2007b). Psychological capital originates from within Positive Organizational Behavior and is made up of four constructs: hope, resilience, optimism, and self-efficacy (Luthans et al. 2006, 2007b). In these terms, psychological capital is conceptualized as the state of positive psychological development of an individual (Luthans et al. 2007b) which implies four elements: first, perseverance in achieving objectives and, when necessary, redirection of the routes to achieve goals (hope); second, capacity to adapt to problems and adversities when they arise, and even to emerge stronger from said situation to achieve success (resilience); third, creation of positive attributions regarding current and future events (optimism); and finally, belief in one's own abilities to make the efforts necessary to achieve success in challenging tasks (self-efficacy).

Several studies have applied this concept to the business environment (Luthans 2002; Wright 2003; Luthans et al. 2004, 2007b; Nelson and Cooper 2007; Luthans and Youssef 2007; Wright and Cropanzano 2007; Avey et al. 2010a), and more recently to that of entrepreneurship, by linking it with business success and entrepreneurial intention, respectively (Luthans et al. 2004; Envick 2005; Hmieleski and Carr 2008; Baker and Sinkula 2009; Hayek 2012; Baluku et al. 2016, 2018, 2021; Zou et al. 2016; Machmud and Ahmad 2019; Wang et al. 2019; Pathak and 
Goltz 2021; Villanueva-Flores et al. 2021). However, to the best of our knowledge, no empirical studies can be found that analyze psychological capital in the field of academic entrepreneurship, although in the literature certain theoretical work refers to the relationship between this capital and the internationalization of companies (Beechler and Javidan 2007; Clapp-Smith et al. 2007; Khilji et al. 2010; Dauth and Tomczak 2016; Mathews 2017).

The impact of psychological factors in the internationalization of companies shows how the personality, abilities, and internal psychological factors of managers can constitute relevant elements (Cabral et al. 2020; Wach and Głodowska 2021). This analysis has been addressed in research such as that by Lai et al. (2017), according to which the internal psychological factors of senior management exert a greater influence on the strategic decision to enter foreign markets than do external factors.

Other research, such as that by Maitland and Sammartino (2015), considers that the decision on internationalization is based on managers' cognition, rather than on their demographic characteristics (Sapienza et al. 2006; Cabral et al. 2020; Wach and Głodowska 2021). Furthermore, Anwar et al. (2018) show that the personality of managers is closely related to the degree of internationalization of their companies. More specifically, several theoretical studies highlight how the personal characteristics (including psychological capital) of the entrepreneur, manager, or leader are related to their mentality, culture, and global leadership, and, therefore, to the internationalization of companies (Beechler and Javidan 2007; Khilji et al. 2010; Dauth and Tomczak 2016; Mathews 2017). Along these lines, Beechler and Javidan (2007) posit that the attributes of the psychological capital of managers are critical components for success in internationalization because they need both self-efficacy to face high levels of ambiguity and difficult tasks in various parts of the world and trust in themselves to face such challenges. Optimism and hope also play a major role in this process, since they provide motivation for the search for alternatives and for the belief in a successful result, regardless of the magnitude of the challenge. Resilience is also relevant due to the higher probabilities of experiencing obstacles in global markets and to the resulting need to continuously adapt.

In the context of ASOs, several of the personality traits that characterize these entrepreneurs have been studied (Kolb and Warner 2015; Obschonka et al. 2019) among the motives of academic entrepreneurs to create an ASO (Bercovitz and Feldman 2003; Ambos et al. 2008), including certain peculiarities inherent in their academic profile (Jain et al. 2009; Guerrero and Urbano 2014; Nielsen 2015). However, no studies on their psychological capital can been found, although certain components have been related individually to academic entrepreneurship. From the literature on entrepreneurship, it is expected that academic entrepreneurs, due to the fact that they have had the courage to commercially exploit their research results, possess certain personality traits related to their entrepreneurial intention, such as presenting high levels of self-efficacy (Prodan and Drnovsek 2010).

Thus, entrepreneurial self-efficacy constitutes a fundamental characteristic that academics must possess in order to overcome their business and entrepreneurial deficiencies and acquire confidence in their abilities and capacities to act in the industrial context, which requires characteristics and a culture that differ from those 
of the university context (Hannibal et al. 2016; Ju and Zhou 2020). According to Hannibal et al. (2016), entrepreneurial self-efficacy motivates academics to act in the markets, which helps them overcome their initial limitations. This self-efficacy has led them to an individual perception related to their ability to successfully complete a task, and consequently the literature has related this variable to entrepreneurial intention (Zhao et al. 2005; Ozgen and Baron 2007; Guerrero et al. 2008; Díaz-García and Jiménez-Moreno 2010; Prodan and Drnovsek 2010; Mathieu and St-Jean 2013; Shinnar et al. 2014; Fernández-Pérez et al. 2014; Huyghe and Knockaert 2015). Self-efficacy can be a mechanism to overcome the financial, technological, and legal uncertainty, which is often associated with entrepreneurship and development in new markets (Markman et al. 2002; Obschonka et al. 2010). Therefore, these levels of self-efficacy can also lead them to perceive that they will be able to successfully tackle the challenge of internationalization. Many of these academic entrepreneurs also come from research fields that lead them to select uncertain environments (Nielsen 2015), such as those that could be related to internationalization.

On the other hand, studies, such as that by Kolb and Warner (2015), indicate that scientists possess high emotional stability, related to self-efficacy and optimism when faced with the high pressure not only of developing excellent research and achievements from their publications, but also of a high workload. These same authors identified a high degree of extraversion in this type of entrepreneur: "A scientist who decides to establish a spin-off is strongly convinced about the business idea, and values the potential outcome of the process highly promising" (p: 403). Within the studies that analyze optimism in the field of academic entrepreneurship are those that indicate that optimism leads entrepreneurs to greater probabilities of starting up a business activity (Díaz-García and Jiménez-Moreno 2010; Abreu and Grinevich 2013; Alonso-Galicia et al. 2015; Iorio et al. 2017).

Regarding resilience, Duchek (2018) relates flexibility to resilience, and authors, such as Zou et al. (2019), point out the high degree of flexibility required of academic entrepreneurs due to their need: to face changing environments; to play a hybrid role, which leads them to manage the conflict inherent in said dual role (Jain et al. 2009); and to manage the distribution of time between the two types of tasks that each of these roles requires. This conflict of roles also leads them to develop different ways of thinking and making decisions. Guerrero and Urbano (2014), for their part, point out how academics take risks and respond to challenges, such as those presented by the internationalization of their businesses. Academic entrepreneurs may encounter multiple issues, ranging from self-motivation issues to social processes in the business venture (for example, they must convince investors and potential employees, customers, and business partners) and must maintain persistence, personal effort, and optimism during the critical and challenging moments of the entrepreneurial process (Cardon et al. 2013).

Finally, to act in an entrepreneurial way and to achieve business objectives requires will power, proactivity, creativity, risk-taking, resilience, and persistence (Cardon et al. 2009). This could be related to the hope component, since those individuals with high levels of hope can maintain the will power and persistence to reach their goals, and to creatively design alternative routes to this end (Avey et al. 2010b). 
The above arguments, and in the absence of studies that focus on the psychological capital of the academic entrepreneur, lead us to suggest that the psychological capital of the academic entrepreneur is important for internationalization. Self-efficacy makes them believe that they have the necessary capacity to face the challenge of internationalization. Regardless of the magnitude of the challenge, optimism and hope encourage them to take the risk to undertake a business venture in global markets, and the motivation to seek alternatives to achieve it. Resilience helps them adapt to the obstacles presented by these global markets. Therefore, the psychological capital of the academic entrepreneur could influence the internationalization of ASOs.

H3. The psychological capital of the academic entrepreneur has a positive impact on the internationalization of ASO

The theoretical model proposed is shown in the following figure (Figure 1).

\section{Method}

\section{Data and sample}

The database includes the population of 628 Spanish ASOs created by Spanish universities with the support of their TTOs during the period 2003-2018. The ASOs in our sample are, on average, 8.57 years old and belong to five different activity sectors. Specifically, 84 ASOs are engaged in professional, scientific, and technical activities; 9 ASOs are engaged in the educational, health, and social sectors; 24 ASOs are engaged in information and communication; 23 ASOs belong to the manufacturing sector; and the remaining, 12 ASOs, are engaged in administrative, auxiliary, and artistic activities. In order to build this database, a formal request for collaboration was requested to RedOTRI who sent an email to all the TTO managers

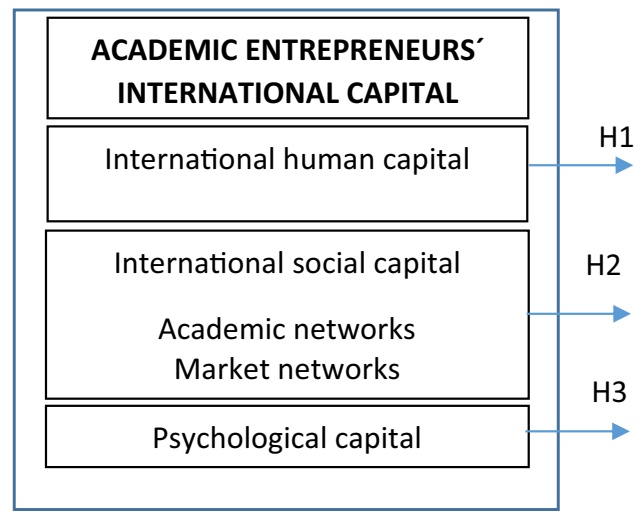

ASO Internationalization

Fig. 1 Conceptual model 
included in this network. The following information was obtained from the managers of 70 Spanish TTOs of ASOs: phone number, email address, web site, company name, founder name, year of constitution, industry, research group, and the identity of the leader of each research group. Subsequently, to design the questionnaire, an exhaustive literature review was generated in order to identify key variables and their measurements. From this literature review, a preliminary questionnaire was designed that was first pretested through in-depth interviews with the academic entrepreneurs and managers of three ASOs in 2018, and their recommendations were considered. The final version of the questionnaire was composed of 21 questions. This questionnaire was sent, by email, to the main founder of each of the 628 Spanish ASOs in our database. These ASOs were created within the university context and their founders are academics, who were still linked to the ASOs at the time the email was sent. Those academic entrepreneurs who failed to respond to the questionnaire by email were contacted by phone. Considering these ASOs and those that participated in the pretest, our sample consisted of 173 established ASOs (response rate: $27.6 \%$ ). In order to ascertain whether there were mean differences between the respondent and non-respondent ASOs in our database, the non-response bias was analyzed. To this end, a $t$-test was applied on independent samples for the comparison of respondent and non-respondent ASOs regarding age and size (number of employees). From these results, it could be demonstrated that there were no mean differences between the respondent and non-respondent ASOs in terms of number of employees $(p=0.310)$ and age $(p=0.139)$. Therefore, non-response bias poses no problem in our empirical data, and therefore, our sample can be assumed as representative of the total population of Spanish ASOs.

\section{Measurement of variables}

\section{Dependent variable}

The dependent variable considered in this study is the degree of internationalization. Numerous alternative metrics were available to measure the firm's degree of internationalization (Sullivan 1994; Asmussen et al. 2007; Baronchelli et al. 2015; Kim 2017). In this work, the degree of internationalization of an ASO is measured through the percentage of international sales to total sales, which constitutes the most commonly used measure (e.g., Kumar and Singh 2008; Kim 2017). Accordingly, the dependent variable takes a value of one if the foreign sales of an ASO exceed 25\% (internationalized ASOs); otherwise, it takes the value zero (domestic ASOs) (Ripolles-Melia et al. 2007).

\section{Independent variable}

Three independent variables are considered in this study: human capital, social capital, and psychological capital. These variables are measured using previously 
established scales. Items on the human capital and psychological capital scales are measured using a 5-point Likert scale ( $1=$ very low grade, $5=$ very high grade). In the case of academic social capital and market social capital, their items have also been measured using a 5-point Likert scale $(1=$ less than one contact per month; $5=$ several daily contacts). With this information, the mean for each of the social capitals is calculated.

International human capital In order to measure this variable, academic entrepreneurs were asked about their international human capital, taking into account both their international experience and training (Sambharya 1996; Carpenter et al. 2003; Björnali and Aspelund 2012). Academic entrepreneurs were asked four questions, on a five-point Likert scale, two related with their previous experience of working in international markets, and two about their international training.

International social capital Based on the classification of agents by Fernández-Alles et al. (2015) and Sousa-Ginel et al. (2017), questions were asked regarding the frequency of academic entrepreneurs' relationships with academic and international market agents for the internationalization of ASOs. The former classification contains university institutions, such as incubators, other academics, university chairs, and research centers, together with TTOs and other universities, while the second classification holds government institutions, industry agents (competitors, customers, and suppliers), technology parks, venture capital firms, and financial agents. To measure social capital, two indicators were employed, one for academic networks and another for market networks. The first is measured with three items, an example of which is "Indicate the frequency with which contacts with other universities take place." The second indicator is measured with 5 items, one of which is "Indicate the frequency with which contacts with technology parks occur." The frequency of ASO international contacts with academic and non-academic networks was measured by asking the principal academic founders to indicate, on a five-point Likert scale, the frequency of contact with each of the actors included in the network (Mitchell 1969; Smith et al. 2005; Sousa-Ginel et al. 2017). From this information, the mean value was calculated.

Psychological capital Psychological capital has been measured through an adaptation of the questionnaire of Luthans et al. (2007b, 2008). This variable is measured through eight items; the scale has been validated and is composed of two items for each of the dimensions that make up the psychological capital: hope (Snyder et al. 1996), resilience (Wagnild and Young 1993), optimism (Scheier and Carver 1985), and self-efficacy (Parker 1998). The scale includes items such as: "I feel confident when representing my work area in meetings with the rest of the members of the management team" (self-efficacy); "I see myself as a successful person in my work" (hope); "When I have a setback at work, I have no problem recovering" (resilience); and "At work, I usually look at the positive side of things" (optimism). 
Control variables According to certain studies, the activity sector and the age of the company are considered as control variables (Franco-Leal et al. 2016; Kim 2017). Five activity sectors were selected and Sector 1 was chosen as the reference category, which was not included in the analysis. The other categories were introduced as dummy variables. Regarding the variable age of the company, this was measured as the natural logarithm of the age of the company.

\section{Results}

Structural equation models (SEMs) are employed to test the proposed hypotheses using the EQS 6.4 program. SEMs are a multivariate statistical analysis technique used to analyze structural relationships. SEMs can perform factor analysis and multiple regression analysis, and they could be used to study structural relationships, between measured variables and latent constructs. This method allows multiple and interrelated dependence to be estimated in a single analysis. Specifically, we used SEMs to perform, first a confirmatory factor analysis (CFA), in order to guarantee the validity and reliability of our scales (Bagozzi et al. 1991), and then, we performed the regressions. They are therefore employed to analyze the structural relationships between variables and latent constructs and enable the estimation of multiple interdependence relationships that may be interrelated in a single analysis.

Subsequently, a Confirmatory Factor Analysis (CFA) is performed to ensure the reliability and validity of the measurement scales. The CFA results are shown in Table 1. One factor is obtained for human capital $(t=5.34)$ and another factor for psychological capital $(t=3.87)$.

Table 2 shows the relative information to guarantee the reliability and validity of the scales following the Fornell and Larcker procedure (1981). Composite reliability is greater than 0.7 in all cases, thus ensuring the reliability of the scales. The average variance extracted (AVE) is, in all cases, greater than 0.5 , these values indicate that the convergent validity is guaranteed.

Discriminant validity is also assured. The results collected in Table 3 show that the square roots of the average variance extracted (AVE), which is the data that appears on the main diagonal, are in all cases superior to the correlations between the different variables selected for this study.

\section{Hypothesis testing}

The hypotheses proposed in this study are tested using structural equation models. The results show a direct and positive relationship between human capital and internationalization. It can therefore be confirmed that Hypothesis H1 is accepted. It is also observed that there is a direct and positive relationship between academic relational capital and internationalization. However, market relational capital does not significantly influence internationalization. These results allow us to ensure that Hypothesis H.2.1 is verified but not Hypothesis H.2.2. There is a direct and positive relationship between psychological capital and the internationalization of ASOs, and therefore, it can be stated that Hypothesis H.3 is verified. Regarding the control variables, the age variable positively 


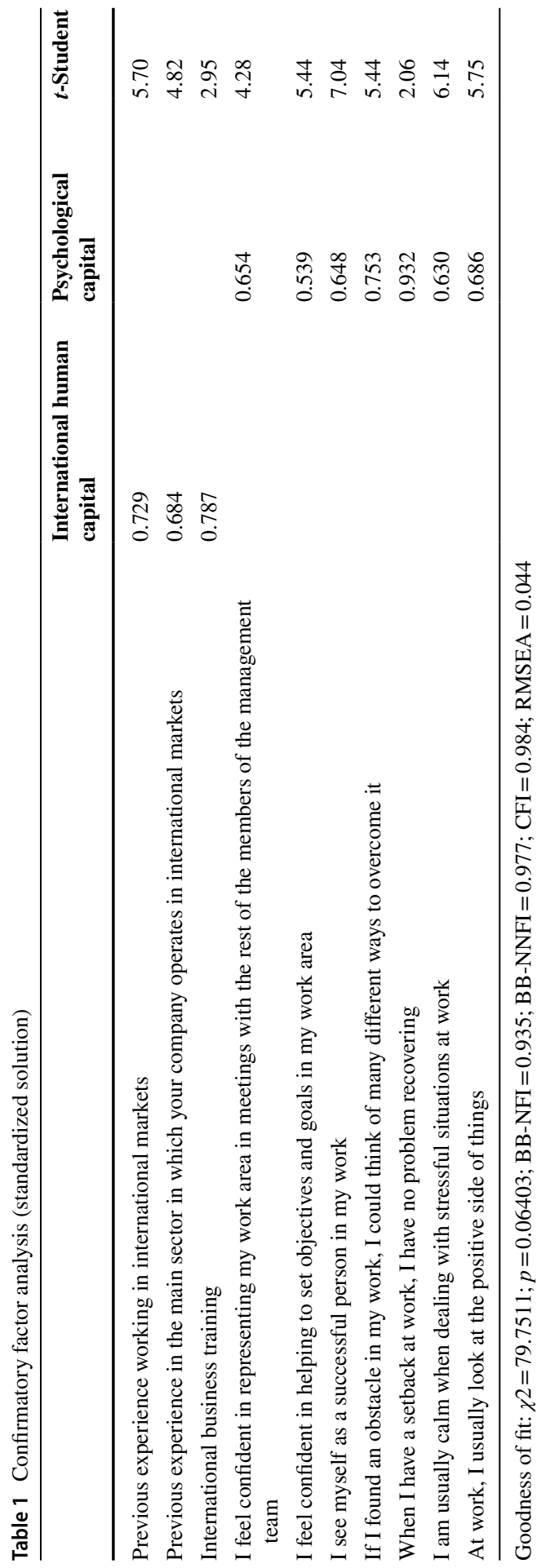


Table 2 Reliability and convergent validity

\begin{tabular}{lll}
\hline & $\begin{array}{l}\text { Composite Reli- } \\
\text { ability }\end{array}$ & AVE \\
\hline International human capital & 0.7781 & 0.5396 \\
Psychological capital & 0.8731 & 0.5012 \\
\hline
\end{tabular}

influences the degree of internationalization. However, the activity sector variable is not significant in any of the cases (Table 4).

\section{Discussion and conclusions}

Our results conclude that international human capital, in terms of international experience and training of the academic entrepreneurs, their networks of relationships with international academic agents, and psychological capital exert a positive impact on the internationalization of ASOs. Several studies, such as that of Beechler and Javidan (2007) and Wach and Głodowska (2021), already argue that senior managers must have a "global mindset" in order to be able to operate successfully on an international level, for which the three capitals analyzed in this work are necessary. Others, such as McDougall et al. (1994), emphasize that companies can be international from the start since their founders possess certain competencies, a global mindset (Weerawardena et al. 2007), and experience and networks (Laanti et al. 2007). Van Geenhuizen et al. (2015) point out that born-global firms arise when there are global networks and a global vision from the outset.

Regarding our first result, previous research focused on analyzing the impact of the entrepreneur's previous international experience on internationalization showed diverse and conflicting results (Kazlauskaitè et al. 2015). Several studies were found that demonstrated negative effects of this experience on internationalization results, such as export intensity (Naudé and Rossouw 2010; Domurath and Patzelt 2020). Liu et al. (2008) revealed, in their case study, that prior international experience of the entrepreneur is not necessary for rapid internationalization. In a study of a four-country sample (China, India, Mexico, and South Africa), others concluded that effects of foreign education on internationalization commitment and speed were insignificant, while foreign work experience had a positive impact. International experience of the entrepreneur was not a necessary resource for rapid internationalization in the case of small and medium-sized Polish firms (Nowiński and Rialp 2013). Entry barriers to international markets were successfully overcome with information and communication technologies that enabled firms to learn about target foreign markets, promote the firm, lower transaction costs, and acquire customers. A case study of Vietnamese born-global firms has also shown that a lack of foreign market knowledge did not serve as a barrier against early internationalization (Thai and Chong 2008). Furthermore, a survey of early Chinese exporters revealed that new international ventures with top managers who had prior experience with a foreign firm were less likely to internationalize early, which again may imply that 


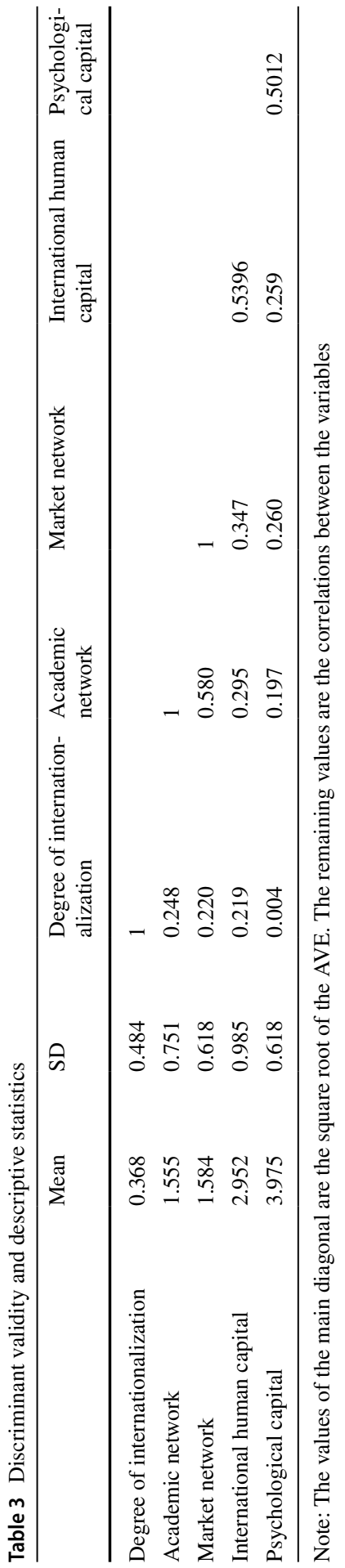


Table 4 Results

\begin{tabular}{ll}
\hline & $\begin{array}{l}\text { Dependent variable: } \\
\text { degree of internationali- } \\
\text { zation }\end{array}$ \\
\hline Company age & $0.175^{* * *}$ \\
Activity sector 2 & $\mathrm{n} . \mathrm{s}$ \\
Activity sector 3 & $\mathrm{n} . \mathrm{s}$ \\
Activity sector 4 & $\mathrm{n} . \mathrm{s}$ \\
International human capital & $0.176^{*}$ \\
Academic networks & $0.225^{* * *}$ \\
Market networks & $\mathrm{n} . \mathrm{s}$ \\
Psychological capital & $0.193^{* * *}$ \\
\hline
\end{tabular}

Goodness of fit: $\chi 2=84.4604 ; p=0.06248 ; \mathrm{BB}-\mathrm{NFI}=0.909$; BB$\mathrm{NNFI}=0.970 ; \mathrm{CFI}=0.978 ; \mathrm{RMSEA}=0.043$

${ }^{* * *} p<0.001 ; * * p<0.05 ; * p<0.1$

international experience is first put to use to boost a firm's competitiveness in the domestic market (Naudé and Rossouw 2010; Kazlauskaite et al. 2015). Björnali and Aspelund (2012) also found that the international experience of managers exerted no influence on the internationalization of the companies they managed.

However, there are also numerous previous investigations that provide evidence of a positive impact of the experience and international training of entrepreneurs on the internationalization of their companies, and our results corroborate this evidence in the case of the founding academic entrepreneurs of ASOs. In certain studies, prior export experience of the entrepreneur was found to be positively associated with the speed of internationalization (Naudé and Rossouw 2010; Ciravegna et al. 2014). Dauth and Tomczak (2016) point out how top management teams with greater international work experience and international training show relatively high levels of foreign sales, and argue that courses and seminars in foreign countries constitute one of the few ways to gain international experience: "interaction with international lecturers, the exposure to foreign languages, and the interaction with foreign participants were factors that enabled Polish managers to broaden their international knowledge" (p: 171). Sekliuckiene (2017) indicates how entrepreneurs that start rapid internationalization had received training abroad. They had international experience and a higher level of education, having worked or studied abroad. The results of Volonté and Gantenbein (2016) also confirm the importance of international experience for companies with a global presence. Herrmann and Datta (2005) encounter evidence of international experience and international diversification strategy. Lindstrand et al. (2011) find that internationalized companies have entrepreneurs with extensive international experience in the sectors in which they operate. Finally, positive results are also presented by Oviatt and McDougall (1994), Bloodgood et al. (1996), Kuemmerle (2002), and McDougall et al. (2003), who point out that the international experience of the entrepreneur could compensate for the lack of collective experience. 
The reason why the results found in the literature are contradictory, may be due to the context of the countries where the studies were conducted. In the work of Kazlauskaitè et al. (2015), the focus is on emerging economies, where the role of experience is less relevant for internationalization; this would not be the case in Spain. Similarly, the work done in Chinese companies have a different business fabric and are more influenced by high domestic competition (Liu et al. 2008; Naudé and Rossouw 2010). Finally, the study by Björnali and Aspelund (2012) explains the negative results of experience in internationalization, due to the heterogeneity of the team composition, and the conflicts that arise within the team.

Regarding the impact of relationship networks in internationalization, a literature review also showed contradictory results (Shirokova and McDougall-Covin 2012; Sekliuckiene 2017). Despite the fact that the majority of studies argue the positive effect of networks on internationalization, many others have found no impact in this process. Within the first of these trends, Vissak (2007) finds that both domestic and international relationship networks played a key role in the speed of the internationalization of companies. The results of the works of Zhou et al. (2007) and Leite et al. (2016) conclude the importance of networks in this process, whereby their speed and success reveal the determining role of social networks. Along the same lines, the work of Johnson (2004) and Coviello and Munro (1995) conclude that rapid internationalization is affected by the company's network of relationships.

Within the work of the second trend, Shirokova and McDougall-Covin (2012) find evidence of the small effect of business and social networks on Russian companies. Musteen et al. (2010) encounter no such relationship between international networks and the speed of internationalization. In this vein, Nowiński and Rialp (2013) have pointed out how companies from emerging countries tend to have limited international relationships and rely more on domestic relationship networks which are more important for their internationalization than are international networks (Kiss and Danis 2008; Shirokova and McDougall-Covin 2012). In the study of 5 bornglobal firms, Rasmussan et al. (2001) find that neither social nor business networks play a major role for the different companies analyzed. Only for certain born-global firms do business networks play a limited role. Along the same lines, the work of Ghannad and Andersson (2012) finds that networks play no important role in the internationalization of Swedish born-global companies. Rasmussan et al. (2001), conclude that the existence of networks at the founding of firms that internationalize early is less important than previously assumed.

Our results are in line with the first trend, since they conclude the positive impact of the relationship networks of the academic entrepreneur on the internationalization of ASOs. However, only academic networks seem to exert a positive influence on this process, as found by studies, such as that of Mikhailova and Olsen (2016), whose results show that it was the international scientific and university networks that promoted the internationalization of their products. These results seem to indicate that it is therefore the original networks of relationships of the academic entrepreneur that arise in the university context from which the most relevant ASOs originate. This is consistent with the results of Hewerdine and Welch (2013), who indicate that internationalization arises during the first phases of the gestation of the idea when the entrepreneur is closely linked to the academic context. Other work 
points out the importance of academic agents in the success of ASOs (Civera et al. 2020), especially that of social networks coming from the academic entrepreneur's inner circle, and these seem to influence internationalization. As Shirokova and McDougall-Covin (2012) point out, relationships based on trust and home-based social networks, such as those established with academic agents, would facilitate key competencies for speed and flexibility in response to global markets (Oviatt and McDougall 2005). However, international entrepreneurial market networks do not seem to be decisive for the internationalization of ASOs, as stated by Musteen et al. (2010) and Hilmersson (2014), who argue that small and medium-sized firms rely more on social networks and personal contacts within the internationalization process. It must be assumed that, due to the very nature of academic entrepreneurship, they tend to have limited relationships with market actors, with some studies having found relationships with governmental and financial actors (Fernández-Alles et al. 2015), but no significant relationships with other actors, such as clients or suppliers. These relationships may be even more limited with international market actors, where some academics may not even have had contact. This is why some previous research recommends that these entrepreneurs distance themselves from the academic context to become more market-oriented (Gübeli and Doloreux 2005; Perez and Sánchez, 2003; Vohora et al. 2004; Fernández-Alles et al. 2015).

These social networks seem to be particularly important for companies that lack business networks (Aldrich and Zimmer 1986; Greve and Salaff 2003), as is the case with ASOs. From these previous investigations, we conclude that networks other than those in the market play a key role in internationalization by providing specific and relevant experiential knowledge for this process.

The psychological capital of academic entrepreneurs seems to be decisive in the internationalization of their business initiatives. The previous literature has already analyzed the impact of this capital on the success of companies (Envick 2005; Hmieleski and Carr 2008; Baluku et al. 2016, 2018; Jin 2017; Machmud and Ahmad 2019; Wang et al. 2019). Only a few studies have analyzed its impact on the internationalization of companies, although this has been carried out through three of the four dimensions that make it up individually. Several of these studies stand out in the context of academic entrepreneurs (Powers and McDougall 2005; Guerrero and Urbano 2014; Prodan and Drnovsek 2010; Abreu and Grinevich 2013; Alonso-Galicia et al. 2015; Fernández-Pérez et al. 2014; Huyghe and Knockaert 2015; Hannibal et al. 2016; Iorio et al. 2017). Regarding the impact of the first dimension of psychological capital on internationalization, work such as that by Oviatt and McDougall (2005) and Wasowska (2019) indicate the impact of self-efficacy on the recognition of international opportunities and the intention to internationalize. With this same dimension, Evald et al. (2011) affirms that possessing self-efficacy can increase the export intention of the entrepreneurs. On the other hand, Kealey (1996) and other authors interpret self-efficacy as an important variable in the effectiveness and intercultural adjustment necessary in international operations (Gertsen 1990; Arthur and Bennett 1995; Jordan and Cartwright 1998; Shaffer et al. 1999; Goldsmith et al. 2003; Hechanova et al. 2003; Harrison et al. 2004; Bhaskar-Shrinivas et al. 2005). Regarding the dimension of optimism, Laguna et al. (2016) point out that positive 
orientation influences the internationalization process of companies, since entrepreneurs with a high positive orientation are more likely to maintain their efforts aimed at achieving objectives, to be more persistent, and to be more committed with foreign markets. Along the same lines, Osland et al. (2006) highlight that optimism is found among the competencies a manager needs for internationalization, and Johanson and Vahlne (1990) reveal it to be a very common characteristic for small companies to begin exporting.

Likewise, Senik et al (2014) explains that among the barriers to internationalization faced by companies stands the negative attitude of the owners or managers of small and medium-sized companies, thereby assuming that optimism and positive attitudes encourage internationalization. Furthermore, Wasowska (2019) states that positive orientation is not only related to the intention of internationalization, but it can also improve self-efficacy and compensate for deficiencies in experience and resources of the entrepreneur. Some authors also highlight that optimism is correlated with the identification of opportunities (Shane and Venkataraman 2000; Gaglio and Katz 2001; Ardichvili et al. 2003; Lumpkin et al. 2004; Zahra et al. 2005; Styles and Seymour 2006; Butler et al. 2010), with the ability to manage uncertainty (Rhinesmith 1996), and with the assumption of risk-taking (Jordan and Cartwright 1998; Mumford et al. 2000). Regarding the resilience dimension, Styles and Seymour (2006) point out that resistance to adversity and perseverance are both key components for the internationalization process. Resilience is an individual capacity that can provide the entrepreneur with the ability to recover in order to face challenging intercultural situations, such as those that arise in internationalization. People who can manage and control their emotions are also better equipped to deploy other global competencies than those with low resilience (Bird et al. 2010). Therefore, effective stress management of resilient people benefits effectiveness in international settings by coping and adapting to the intercultural complexity of global markets (Gertsen 1990; Kealey 1996; Shaffer et al. 2006). Rahman and Mendy (2018) state that certain barriers to internationalization that companies face, such as, language challenges, social and cultural differences, and the lack of skilled labor or facilities, could be managed or improved through resilience.

Although there are no studies that link hope with internationalization, since this attribute makes the individual set goals and objectives and look for alternatives to achieve, we understand that those companies led by people with hope remain persistent in the search for international objectives, and persevere towards the business goal of internationalization. A greater drive to strive towards business goals is attained in this way, as is the ability to identify multiple alternative plans to achieve business goals more successfully (Envick 2005). Hope increases the intention to undertake the methods to attain results and is positively related to business success and especially to the survival of the company (Baluku et al. 2016, 2018). Furthermore, the capacities that comprise hope improve self-efficacy and business optimism (DiPietro et al. 2007). Additionally, Osland et al. (2006) and Jordan and Cartwright (1998) mention that an international manager must be able to visualize different patterns and alternatives, which could be related to the capacity of the manager to have levels of hope. 
In line with work by Kim (2017), the control variable, age of the ASO, is found to be significant in explaining the internationalization of ASOs. This seems to suggest that those academics who have successfully established themselves in the marketplace, over time, are able to take advantage of their experience and knowledge obtained as they plan to enter international markets. However, the control variable industry type was not significant, as certain authors point out (Franco-Leal et al. 2016; Kim 2017).

These results cannot be discussed without taking into account the impact of the Spanish context which, from the perspective of academic transfer and entrepreneurship, is not very conducive when compared to other European countries (Seguí-Mas et al. 2018). Firstly, this is due to the financial crisis which has resulted in austerity policies, cuts in public investment for entrepreneurship, and heavy credit restrictions, especially for SMEs such as ASOs. Secondly, this is because it is socio-culturally a country with a high aversion to risk-taking in business ventures. Thirdly, it is because the legal policy framework recognizes the opportunity of transfer, but does not encourage it. Finally, Spain has few resources for innovation, which hinders academic entrepreneurial activity (Davey et al. 2016). However, the peculiarities of this context have motivated academics to start their own businesses, and seek new opportunities. This leads us to conclude the importance, within the Spanish context, of the figure of the academic entrepreneur, the protagonist of the process. This result is consistent with the findings of Guerrero and Urbano (2012), who concluded that the attitudes and intentions of academics are the most relevant factor for entrepreneurship in Spain. On the other hand, Fernández Alles and Ramos-Rodríguez (2021:100) point out that “... academic entrepreneurs in Spain have important reputational networks with foreign universities and researchers and, above all, with institutes and research groups in other countries, which could facilitate access to international markets, not only because of the international nature of these collaborations, but also because of the reputation that would confer credibility to the ASOs ...." Finally, Spanish academics tend to have completed part of their training abroad, as international mobility is a requirement to obtaining accreditations and positions in universities.

Therefore, we can conclude that international human capital, international academic social capital, and the psychological capital of academic entrepreneurs are fundamental to the internationalization of ASOs.

\section{Implications}

\section{Implications for theory}

We contribute to RBV and NT, as well as to the literature on academic entrepreneurship and internationalization, by explaining how the profiles of academic entrepreneurs influence the international projection of their business initiatives, in terms of their international human capital, international networks, and psychological capital. The three capitals of the academic entrepreneur are key resources for 
the internationalization of ASOs. This is both through the entrepreneur's human and psychological capital, as well as through the international academic networks.

In relation to our first result, and given the existence of conflicting results regarding the impact of human capital on the internationalization of companies, we have valued the importance of the experience, training, and international mobility of academic entrepreneurs for the resources that they could provide for internationalization. Although the work that revolves around this subject has largely been focused on the study of management teams and entrepreneurs, a few have been oriented towards the analysis of academic entrepreneurs, who, due to their research and scientific activity, have extensive experience and international training that undoubtedly contribute to the internationalization of their businesses.

Second, we contribute towards the NT, by analyzing the peculiarities of the networks of relationships of academic entrepreneurs on internationalization. Since these entrepreneurs come from an academic context, their network of relationships has certain particular characteristics that undoubtedly affect their propensity to commercialize their research results in international markets. On the one hand, these are fundamentally university networks, and on the other hand, they are international networks derived from their collaboration with agents and institutions with which they work for the advancement of their academic activity.

Regarding the literature on academic entrepreneurship, an important contribution of our work entails the study of the psychological capital, whose analysis has hitherto been largely dismissed in this literature, together with the other two capitals of interest: human and relational capital. Therefore, our results bring to light the analysis of the impact of the profile of the academic entrepreneur in the internationalization of ASOs, by employing three capitals of this entrepreneur that have not previously been considered empirically in this literature together.

This article therefore increases the knowledge regarding antecedents in the analysis of the internationalization of ASOs, since it improves the understanding of the factors that influence the decision to enter international markets. Therefore, international human capital, academic networks, and psychological capital should be considered as important international business resources.

On the other hand, this work contributes towards the literature on internationalization, by specifically analyzing the internationalization of ASOs. ASOs are created with a strong international vocation, not only due to the type of sector in which they operate, the market niches towards which they are directed, and the major investments that must be profitable, but also in light of our results, because these are companies run by people with high level of international experience, academic networks of global relationships, and with a personal predisposition to self-efficacy, resilience, optimism, and hope. All of these variables are related to the challenge and difficulties involved in tackling non-domestic markets.

\section{Practical implications}

Our results, given the importance in universities of knowledge transfer and, in accordance with the triple helix model, revealed certain practical implications. Firstly, regarding 
human capital, academic institutions should help academic entrepreneurs, by means of advice or training, to enhance the internationalization of their ASOs through the recognition of global opportunities, the development of business plans aimed at foreign markets, and the identification of potential customers, needs, or non-domestic marketing channels, based on the international experiences that they have accumulated as a result of their collaboration networks, their training, and international mobility. Secondly, institutions should encourage the establishment of collaboration networks with agents from the international university context, from the conviction that these close relationships, from the context closest to the academic entrepreneur, seem to be decisive for the internationalization of their companies. To this end, more resources should be allocated to building these relationships with other universities, research groups, foreign TTOs, and with other non-local academic institutions. Thirdly, in relation to psychological capital, our results highlight significant implications for academic policies, which should carry out psychological capital interventions to develop academic entrepreneurs' psychological capital (Bandura 1997; Masten 2001; Luthans et al. 2007a; 2010; 2015; Hizam-Hanafiah et al. 2017). Consequently, training programs could reinforce their psychological capital, since this could help them overcome their doubts and fears about embracing international entrepreneurship, thereby enhancing the probability of incorporating risky strategies such as internationalization. Self-efficacy, hope, optimism, and resilience of academic entrepreneurs can be effectively developed in short training interventions for them to face new challenges, such as those involved in approaching foreign markets. These implications, focused on the academic entrepreneur, are especially relevant given the unfavorable context for entrepreneurship in Spain.

There are three limitations in our work that must be taken into account. The first limitation involves the way of collecting the network data. Since networks are dynamic and change over time, the collected data may suffer from memory bias. Scholars have found that the effect of networks can be temporary and is influenced by the external environment. Secondly, our sample draws from Spanish ASOs, and therefore the results achieved could differ for samples from other countries. Thirdly, the opinion of the other co-founders is not taken into account, and only the main founders of the ASOs was asked to respond to the questionnaire. For future research, we recommend that the proposed model be validated using samples from other countries to establish comparisons. In addition, it would be of great interest to study the impact between the three capitals, as some authors have shown that psychological capital can influence social and human capital (Envick 2005; Zhao et al. 2020). Finally, further analysis is necessary to study how the impact of networks can be observed longitudinally.

Funding Open Access funding provided thanks to the CRUE-CSIC agreement with Springer Nature. This work has been co-financed by the 2020-2023 ERDF Operational Programme and by the Department of Economy, Knowledge, Business and University of the Regional Government of Andalusia. Project reference: FEDER-UCA18-107689 titled "Analysis of the influence of the Andalusian, Spanish and European entrepreneurial ecosystems on the internationalization process of Andalusian academic spin-offs, and its impact on innovation results".

Open Access This article is licensed under a Creative Commons Attribution 4.0 International License, which permits use, sharing, adaptation, distribution and reproduction in any medium or format, as long as you give appropriate credit to the original author(s) and the source, provide a link to the Creative 
Commons licence, and indicate if changes were made. The images or other third party material in this article are included in the article's Creative Commons licence, unless indicated otherwise in a credit line to the material. If material is not included in the article's Creative Commons licence and your intended use is not permitted by statutory regulation or exceeds the permitted use, you will need to obtain permission directly from the copyright holder. To view a copy of this licence, visit http://creativecommons.org/ licenses/by/4.0/.

\section{References}

Abreu M, Grinevich V (2013) The nature of academic entrepreneurship in the UK: widening the focus on entrepreneurial activities. Res Policy 42(2):408-422

Acedo J, Casillas F (2007) Age at entry in international markets of Spanish SMEs: entrepreneurial and institutional determinants. Int J Entrep Behav Res 13(3):130-150

Aldrich HE, Zimmer C (1986) Entrepreneurship through social networks a reconsideration of the theory of entrepreneurship: a participatory approach. Population Perspectives on Organizations 13-28.

Algieri B, Aquino A, Succurro M (2013) Technology transfer offices and academic spin-off creation: the case of Italy. J Technol Transf 38(4):382-400

Alonso-Galicia PE, Fernández-Pérez V, Rodríguez-Ariza LM, Fuentes-Fuentes M (2015) Entrepreneurial cognitions in academia: exploring gender differences. J Manag Psychol 30(6):630-644

Anwar M, Shah SZA, Khan SZ (2018) The role of personality in SMEs internationalization: empirical evidence. Rev Int Bus Strategy 28(2):258-282

Amal M, Freitag Filho AR, Miranda CMS (2008) Algumas evidências sobre o papel das redes de relacionamento e empreeendedorismo na internacionalização das pequenas e médias empresas. Rev Adm FACES J 7(1):63-80

Ambos TC, Mäkelä K, Birkinshaw J, D'Este P (2008) When does university research get commercialized? Creating ambidexterity in research institutions. J Manage Stud 45(8):1424-1447

Andersson S, Berggren E (2016) Born global or local? Factors influencing the internationalization of university spin-offs-the case of Halmstad University. J Int Entrep 14(3):296-322

Andersson S, Evers N, Griot C (2013) Local and international networks in small firm internationalization: cases from the Rhône-Alpes medical technology regional cluster. Entrep Reg Dev 25(9-10):867-888

Ardichvili A, Cardozo R, Ray S (2003) A theory of entrepreneurial opportunity identification and development. J Bus Ventur 18(1):105-123

Arthur W Jr, Bennett W Jr (1995) The international assignee: the relative importance of factors perceived to contribute to success. Pers Psychol 48(1):99-114

Asmussen CG, Pedersen T, Petersen B (2007) How do we capture "global specialization" when measuring firms' degree of globalization? Manag Int Rev 47(6):791-813

Athanassiou N, Nigh D (2002) The impact of the top management team's international business experience on the firm's internationalization: social networks at work. Manag Int Rev 42(2):157-181

Audretsch D, Aldridge T (2012) Transnational social capital and scientist entrepreneurship. J Manage Governance 16(3):369-376

Avey JB, Nimnicht JL, Pigeon NG (2010a) Two field studies examining the association between positive psychological capital and employee performance. Leadersh Org Dev J 31(5):384-401

Avey JB, Luthans F, Youssef CM (2010b) The additive value of positive psychological capital in predicting work attitudes and behaviors. J Manag 36(2):430-452

Bagozzi RP, Yi Y, Phillips LW (1991) Assessing construct validity in organizational research. Adm Sci Q 36(3):421-458

Baker WE, Sinkula JM (2009) The complementary effects of market orientation and entrepreneurial orientation on profitability in small businesses. J Small Bus Manage 47(4):443-464

Baluku MM, Kikooma JF, Kibanja GM (2016) Psychological capital and the startup capital-entrepreneurial success relationship. J Small Bus Entrep 28(1):27-54

Baluku MM, Kikooma JF, Bantu E, Otto K (2018) Psychological capital and entrepreneurial outcomes: the moderating role of social competences of owners of micro-enterprises in East Africa. J Glob Entrep Res 8(1):1-23 
Baluku MM, Onderi P, Otto K (2021) Predicting self-employment intentions and entry in Germany and East Africa: an investigation of the impact of mentoring, entrepreneurial attitudes, and psychological capital. J Small Bus Entrep 33(3):289-322

Bandura A (1997) The nature and structure of self-efficacy. Self-efficacy: the exercise of control. New York, NY: WH Freeman and Company 37-78.

Baum M, Schwens C, Kabst R (2015) A latent class analysis of small firms' internationalization patterns. J World Bus 50(4):754-768

Bhaskar-Shrinivas P, Harrison DA, Shaffer MA, Luk DM (2005) Input-based and time-based models of international adjustment: meta-analytic evidence and theoretical extensions. Acad Manag $\mathrm{J}$ 48(2):259-281

Bird A, Mendenhall M, Stevens MJ, Oddou G (2010) Defining the content domain of intercultural competence for global leaders. J Manag Psychol 25(8):810-828

Bai W, Johanson M, Oliveira L, Ratajczak-Mrozek M (2021) The role of business and social networks in the effectual internationalization: insights from emerging market SMEs. J Bus Res 129:96-109

Baronchelli G, Cassia F, Piantoni M (2015) TMT international orientation and firm internationalisation: evidence from Italy. Int J Manag Pract 8(4):296-315

Beechler S, Javidan M (2007) Leading with a global mindset. Adv Int Manag 19(7):131-169

Bercovitz J, Feldman M (2003) Technology transfer and the academic department: who participates and why. In DRUID summer conference 15:12-14

Bialek-Jaworska A, Gabryelczyk R (2016) Biotech spin-off business models for the internationalization strategy. Balt J Manag 11(4):380-404

Björnali ES, Aspelund A (2012) The role of the entrepreneurial team and the board of directors in the internationalization of academic spin-offs. J Int Entrep 10(4):350-377

Bloodgood JM, Sapienza HJ, Almeida JG (1996) The internationalization of new high-potential US ventures: antecedents and outcomes. Entrep Theory Pract 20(4):61-76

Bruneel J, Clarysse B, Autio E (2018) The role of prior domestic experience and prior shared experience in young firm internationalization. Int Small Bus J 36(3):265-284

Butler JE, Doktor R, Lins FA (2010) Linking international entrepreneurship to uncertainty, opportunity discovery, and cognition. J Int Entrep 8(2):121-134

Cabral ÂMR, Carvalho FMP, Ferreira JAV (2020) SMEs' international strategic groups and top managers' psychological characteristics. Adm Sci 10(4):1-22

Cardon MS, Wincent J, Singh J, Drnovsek M (2009) The nature and experience of entrepreneurial passion. Acad Manag Rev 34(3):511-532

Cardon MS, Gregoire DA, Stevens CE, Patel PC (2013) Measuring entrepreneurial passion: conceptual foundations and scale validation. J Bus Ventur 28(3):373-396

Carpenter MA, Sanders GWM, Gregersen HB (2001) Bundling human capital with organizational context: the impact of international assignment experience on multinational firm performance and CEO pay. Acad Manag J 44(3):493-511

Carpenter MA, Pollock TG, Leary MM (2003) Testing a model of reasoned risk taking: governance, the experience of principals and agents, and global strategy in high technology IPO firms. Strateg Manag J 24(9):803-820

Clapp-Smith R, Luthans F, Avolio BJ (2007) The role of psychological capital in global mindset development. Adv Int Manag: Global Mindset 19:105-130

Clarysse B, Wright M, Lockett A, Van de Velde E, Vohora A (2005) Spinning out new ventures: a typology of incubation strategies from European research institutions. J Bus Ventur 20(2):183-216

Ciravegna L, Lopez L, Kundu S (2014) Country of origin and network effects on internationalization: a comparative study of SMEs from an emerging and developed economy. J Bus Res 67(5):916-923

Civera A, Meoli M, Vismara S (2019) Do academic spinoffs internationalize? J Technol Transf 44(2):381-403

Civera A, Donina D, Meoli M, Vismara S (2020) Fostering the creation of academic spinoffs: does the international mobility of the academic leader matter? Int Entrepreneurship Manag J 16(2):439-465

Conceição O, Fontes M, Calapez T (2012) The commercialisation decisions of research-based spinoff: targeting the market for technologies. Technovation 32(1):43-56

Coviello NE, Munro HJ (1995) Growing the entrepreneurial firm. Eur J Mark 29(7):49-61

Coviello N, Munro H (1997) Network relationships and the internationalisation process of small software firms. Int Bus Rev 6(4):361-386

Coviello NE (2006) The network dynamics of international new ventures. J Int Bus Stud 37(5):713-731 
Coviello NE, Cox MP (2006) The resource dynamics of international new venture networks. J Int Entrep 4(2-3):113-132

Dana LP (2001) Networks, internationalization \& policy. Small Bus Econ 16(2):57-62

Dauth T, Tomczak A (2016) Internationalization of top management teams: a comprehensive analysis of Polish stock-listed firms. J East Eur Manag Stud 21(2):167-183

Davey T, Rossano S, Van Der Sijde P (2016) Does context matter in academic entrepreneurship? The role of barriers and drivers in the regional and national context. J Technol Transf 41(6):1457-1482

De Cleyn SH, Braet J, Klofsten M (2011) How do human and social capital contribute to the early development of academic spin-off ventures? Front Entrep Res 31(17):567-581

Díaz-García MC, Jiménez-Moreno J (2010) Entrepreneurial intention: the role of gender. Int Entrep Manag J 6(3):261-283

Di Gregorio D, Shane S (2003) Why do some universities generate more start-ups than others? Res Policy 32(2):209-227

DiPietro RB, Dianne HB, Welsh PV, Raven DS (2007) A measure of hope in franchise systems: assessing franchisees, top executives, and franchisors. J Leadersh Organ Stud 13(3):59-66

Domurath A, Patzelt H (2020) Founder non-international experience and venture internationalization. J Int Entrep 17(4):494-519

Duchek S (2018) Entrepreneurial resilience: a biographical analysis of successful entrepreneurs. Int Entrep Manag J 14(2):429-455

Ellis P, Pecotich A (2001) Finding international exchange partners: the role of social ties. Glob Focus 13(2):121-133

Envick BR (2005) Beyond human and social capital: the importance of positive psychological capital for entrepreneurial success. Entrep Exec 10:41-52

Evald MR, Klyver K, Christensen PR (2011) The effect of human capital, social capital, and perceptual values on nascent entrepreneurs' export intentions. J Int Entrep 9(1):1-19

Evers N, O'Gorman C (2011) Improvised internationalization in new ventures: the role of prior knowledge and networks. Entrep Reg Dev 23(7-8):549-574

Evers N, Cunningham JA, Hoholm T (2016) International entrepreneurship in universities: context, emergence and actors. J Int Entrep 14(3):285-295

Etzkowitz H, Leydesdorff L (2000) The dynamics of innovation: from National Systems and "Mode 2" to a Triple Helix of university-industry-government relations. Res Policy 29(2):109-123

Etzkowitz H (2003) Innovation in innovation: the triple helix of university-industry-government relations. Soc Sci Inf 42(3):293-337

Etzkowitz H, Zhou C (2017) The triple helix: university-industry-government innovation and entrepreneurship. Routledge

Fernhaber SA, Mcdougall-Covin PP, Shepherd DA (2009) International entrepreneurship: leveraging internal and external knowledge sources. Strateg Entrep J 3(4):297-320

Fernández-Alles M, Camelo-Ordaz C, Franco-Leal N (2015) Key resources and actors for the evolution of academic spin-offs. J Technol Transf 40(6):976-1002

Fernández-Alles ML, Ramos Rodríguez R (2021) El potencial internacional de las spin-off académicas en España. Señales de credibilidad de los emprendedores académicos para la legitimidad de las spinoffs académicas. Editorial Universidad de Cádiz.

Fernández-Pérez V, Alonso-Galicia PE, Fuentes-Fuentes M, Rodriguez-Ariza L (2014) Business social networks and academics' entrepreneurial intentions. Ind Manag Data Syst 114(2):292-320

Fitzgerald J, Ojanperä S, O'Clery N (2021) Is academia becoming more localised? The growth of regional knowledge networks within international research collaboration. Appl Netw Sci 6(1):1-27

Fornell C, Larcker DF (1981) Structural equation models with unobservable variables and measurement error: algebra and statistics. J Mark Res 18(3):382-388

Franco-Leal N, Soetanto D, Camelo-Ordaz C (2016) Do they matter? The role of non-academics in the internationalization of academic spin-offs. J Int Entrep 14(3):410-440

Franco-Leal N, Camelo-Ordaz C, Fernandez-Alles M, Sousa-Ginel E (2020) The entrepreneurial ecosystem: actors and performance in different stages of evolution of academic spinoffs. Entrep Res J 10(2):1-21

Franklin SJ, Wright M, Lockett A (2001) Academic and surrogate entrepreneurs in university spin-out companies. J Technol Transf 26(1-2):127-141

Gaglio CM, Katz JÁ (2001) The psychological basis of opportunity identification: entrepreneurial alertness. Small Bus Econ 16(2):95-111

Gertsen MC (1990) Intercultural competence and expatriates. Int J Hum Resour Manag 1(3):341-362 
Gajowiak M (2013) The role of social capital in the activities of internationalized food processing SMEs. Confrontation of Theoretical Findings with Empirical Ones. Oeconomia Copernicana 4(4):59-76

Ghannad N, Andersson S (2012) The influence of the entrepreneur's background on the behaviour and development of born globals' internationalisation processes. Int J Entrep Small Bus 15(2):136-153

Goldsmith M, Greenberg C, Robertson A, Hu-Chan M (2003) Global leadership: the next generation, prentice-hall, upper Saddle River, NJ.

Greve A, Salaff JW (2003) Social networks and entrepreneurship. Entrep Theory Pract 28(1):1-22

Guerrero M, Rialp J, Urbano D (2008) The impact of desirability and feasibility on entrepreneurial intentions: a structural equation model. Int Entrep Manag J 4(1):35-50

Guerrero M, Urbano D (2012) The development of an entrepreneurial university. J Technol Transf 37(1):43-74

Guerrero M, Urbano D (2014) Academics' start-up intentions and knowledge filters: an individual perspective of the knowledge spillover theory of entrepreneurship. Small Bus Econ 43(1):57-74

Gübeli MH, Doloreux D (2005) An empirical study of university spin-off development. Eur J Innov Manag 8(3):269-282

Haahti A, Madupu V, Yavas U, Babakus E (2005) Cooperative strategy, knowledge intensity and export performance of small and medium sized enterprises. J World Bus 40(2):124-138

Hambrick DC, Mason PA (1984) Upper echelons: the organization as a reflection of its top managers. Acad Manag Rev 9(2):193-206

Hannibal M, Evers N, Servais P (2016) Opportunity recognition and international new venture creation in university spin-offs-cases from Denmark and Ireland. J Int Entrep 14(3):345-372

Harrison DA, Shaffer MA, Bhaskar-Shrinivas P (2004) Going places: roads more and less traveled in research on expatriate experiences. Res Pers Hum Resour Manag 23:199-247

Hayek M (2012) Control beliefs and positive psychological capital. J Manag Res 12(1):3-13

Hayter CS (2015) Social networks and the success of university spin-offs: toward an agenda for regional growth. Econ Dev Q 29(1):3-13

Hechanova R, Beehr TA, Christiansen ND (2003) Antecedents and consequences of employees adjustment to overseas assignment: a meta-analytic review. Appl Psychol: an Int Rev 52(2):213-236

Herrmann P, Datta DK (2005) Relationships between top management team characteristics and international diversification: an empirical investigation. Br J Manag 16(1):69-78

Hewerdine L, Welch C (2013) Are international new ventures really new? A process study of organizational emergence and internationalization. J World Bus 48(4):466-477

Hilmersson M (2014) Experiential knowledge types and profiles of internationalising small and mediumsized enterprises. Int Small Bus J 32(7):802-817

Hizam-Hanafiah M, Yousaf SU, Usman B (2017) The influence of psychological capital on the growth intentions of entrepreneurs: a study on Malaysian SME entrepreneurs. Bus Econ Horiz (BEH) 13(5):556-569

Hmieleski KM, Carr JC (2008) The relationship between entrepreneur psychological capital and new venture performance. Front Entrep Res 28:1-12

Holmlund M, Kock S (1998) Relationships and the internationalisation of Finnish small and mediumsized companies. Int Small Bus J 16(4):46-63

Huyghe A, Knockaert M (2015) The influence of organizational culture and climate on entrepreneurial intentions among research scientists. J Technol Transf 40(1):138-160

Iorio R, Labory S, Rentocchini F (2017) The importance of pro-social behaviour for the breadth and depth of knowledge transfer activities: an analysis of Italian academic scientists. Res Policy 46(2):497-509

Jain S, George G, Maltarich M (2009) Academics or entrepreneurs? Investigating role identity modification of university scientists involved in commercialization activity. Res Policy 38(6):922-935

Jin $\mathrm{CH}$ (2017) The effect of psychological capital on start-up intention among young start-up entrepreneurs. Chin Manag Stud 11(4):707-729

Johanson J, Vahlne JE (1990) The mechanism of internationalization. Int Mark Rev 7(4):11-24

Johanson J, Mattsson LG (1985) Marketing investments and market investments in industrial networks. Int J Res Mark 2(3):185-195

Johanson J, Mattsson LG (1988) Internationalisation in industrial systems-a network approach.

Johnson JE (2004) Factors influencing the early internationalization of high technology start-ups: US and UK evidence. J Int Entrep 2(1-2):139-154

Jordan J, Cartwright S (1998) Selecting expatriate managers: key traits and competencies. Leadersh Org Dev J 19(2):89-96 
Ju W, Zhou X (2020) Institutional environment and entrepreneurial intention of academics in China. Soc Behav Personal Int J 48(4):1-15

Kamakura WA, Ramon-Jeronimo MA, Gravel JDV (2012) A dynamic perspective to the internationalization of small-medium enterprises. J Acad Mark Sci 40(2):236-251

Karlsson T, Wigren C (2012) Start-ups among university employees: the influence of legitimacy, human capital and social capital. J Technol Transf 37(3):297-312

Kazlauskaitė R, Autio E, Sarapovas T, Abramavicius S, Gelbuda M (2015) The speed and extent of new venture internationalisation in the emerging economy context. Entrep Bus Econ Rev 3(2):41-52

Kealey DJ (1996) The challenge of international personnel selection. In: Landis D, Bhagat RS (eds) Handbook of Intercultural Training, 2nd edn. Sage Publications, Thousand Oaks CA, pp 81-105

Khilji SE, Davis EB, Cseh M (2010) Building competitive advantage in a global environment: leadership and the mindset. In T. Devinney; T. Pedersen \& Tihanyi, L. (eds.) The past, present and future of international business \& management. Emerald Group Publishing Limited 23:353-373.

Kim KS (2017) Factors affecting the internationalization of small and medium-sized enterprises in South Korea: entrepreneurial orientation, human capital and technological capabilities. Int J Econ Financ Issues 7(5):371-379

Kiss AN, Danis WM (2008) Country institutional context, social networks, and new venture internationalization speed. Eur Manag J 26(6):388-399

Kiss AN, Danis WM, Cavusgil ST (2012) International entrepreneurship research in emerging economies: a critical review and research agenda. J Bus Ventur 27(2):266-290

Kolb C, Wagner M (2015) Crowding in or crowding out: the link between academic entrepreneurship and entrepreneurial traits. J Technol Transf 40(3):387-408

Krabel S, Siegel DS, Slavtchev V (2012) The internationalization of science and its influence on academic entrepreneurship. J Technol Transf 37(2):192-212

Kuemmerle W (2002) Home base and knowledge management in international ventures. J Bus Ventur 17(2):99-122

Kumar V, Singh N (2008) Internationalization and performance of Indian pharmaceutical firms. Int Bus Rev 50(5):321-330

Laanti R, Gabrielsson M, Gabrielsson P (2007) The globalization strategies of business-to-business born global firms in the wireless technology industry. Ind Mark Manage 36(8):1104-1117

Laguna M, Alessandri G, Caprara GV (2016) Personal goal realisation in entrepreneurs: a multilevel analysis of the role of affect and positive orientation. Appl Psychol 65(3):587-604

Lai JH, Lin WC, Chen LY (2017) The influence of CEO overconfidence on ownership choice in foreign market entry decisions. Int Bus Rev 26(4):774-785

Lamotte O, Colovic A (2015) Early internationalization of new ventures from emerging countries: the case of transition economies. Dans Management 18(1):8-30

Laurell H, Andersson S, Achtenhagen L (2013) The importance of industry context for new venture internationalisation: a case study from the life sciences. J Int Entrep 11(4):297-319

Laurell H, Achtenhagen L, Andersson S (2017) The changing role of network ties and critical capabilities in an international new venture's early development. Int Entrep Manag J 13(1):113-140

Lehto I (2015) International entrepreneurial selling as construction of international opportunities. J Int Entrep 13(3):277-302

Leite YVP, De Moraes WFA, Salazar VS (2016) Expressions of relationship networking in international entrepreneurship. J Int Entrep 14(2):213-238

Leonidou LC, Katsikeas CS (1996) The export development process: an integrative review of empirical models. J Int Bus Stud 27(3):517-551

Libaers D, Wang T (2012) Foreign-born academic scientists: entrepreneurial academics or academic entrepreneurs? R\&D Management 42(3):254-272

Lindstrand A, Melén S, Nordman ER (2011) Turning social capital into business: a study of the internationalization of biotech SMEs. Int Bus Rev 20(2):194-212

Liu X, Xiao W, Huang X (2008) Bounded entrepreneurship and internationalisation of indigenous Chinese private-owned firms. Int Bus Rev 17(4):488-508

Liu L, Henley J, Mousavi MM (2021) Foreign interfirm networks and internationalization: evidence from sub-Saharan Africa. J Int Manag 27(1):1-18

Loane S, Bell J (2006) Rapid internationalisation among entrepreneurial firms in Australia, Canada, Ireland and New Zealand: an extension to the network approach. Int Mark Rev 23(5):467-485

Lukason O, Vissak T, Segovia-Vargas MJ (2021) How does managerial experience predict the internationalization type of a young firm? IEEE Access 9:18148-18166 
Lumpkin GT, Hills GE, Shrader R (2004) Opportunity recognition. In: Welsch HP (ed) Entrepreneurship: the way ahead. Psychology Press, New York, pp 73-90

Luthans F (2002) The need for and meaning of positive organizational behavior. J Organ Behav: Int J Ind, Occup Organ Psychol Behav 23(6):695-706

Luthans F, Luthans KW, Luthans BC (2004) Positive psychological capital: beyond human and social capital. Bus Horiz 47(1):45-50

Luthans F, Avey JB, Avolio BJ, Norman SM, Combs GM (2006) Psychological capital development: toward a micro intervention. J Organ Behav: Int J Ind, Occup Organ Psychol Behav 27(3):387-393

Luthans F, Youssef CM, Avolio BJ (2007a) Psychological capital. Oxford University Press, Oxford, UK

Luthans F, Avolio BJ, Avey JB, Norman SM (2007b) Positive psychological capital: measurement and relationship with performance and satisfaction. Pers Psychol 60(3):541-572

Luthans F, Youssef CM (2007) Emerging positive organizational behavior. J Manag 33(3):321-349

Luthans F, Avey JB, Clapp-Smith R, Li W (2008) More evidence on the value of Chinese workers' psychological capital: a potentially unlimited competitive resource? Int J Hum Resour Manag 19(5):818-827

Luthans F, Avey JB, Avolio BJ, Peterson SJ (2010) The development and resulting performance impact of positive psychological capital. Hum Resour Dev Q 21(1):41-67

Luthans F, Youssef CM, Avolio BJ (2015) Psychological capital and beyond. Oxford University Press, USA

Maitland E, Sammartino A (2015) Managerial cognition and internationalization. J Int Bus Stud 46(7):733-760

Mathews J (2017) The structure and development of global mindset. IUP J Organ Behav 16(4):7-33

Mathieu C, St-Jean É (2013) Entrepreneurial personality: the role of narcissism. Personality Individ Differ 55(5):527-531

Masten AS (2001) Ordinary magic: resilience processes in development. Am Psychol 56(3):227-238

McDougall PP, Shane S, Oviatt BM (1994) Explaining the formation of international new ventures: the limits of theories from international business research. J Bus Ventur 9(6):469-487

McDougall PP, Oviatt BM, Shrader RC (2003) A comparison of international and domestic new ventures. J Int Entrep 1(1):59-82

Machmud A, Ahman E (2019) Effect of entrepreneur psychological capital and human resources on the performance of the catering industry in Indonesia. J Entrep Educ 22(1):1-7

Markman GD, Balkin DB, Baron RA (2002) Inventors and new venture formation: the effects of general self-efficacy and regretful thinking. Entrep Theory Pract 27(2):149-165

Mikhailova O, Olsen PI (2016) Internationalization of an academic invention through successive sciencebusiness networks: the case of TAVI. J Int Entrep 14(3):441-471

Mitchell JC (1969) The concept and use of social networks. Social networks in urban situations. Bobbs Merril.

Mohr A, Batsakis G (2014) Intangible assets, international experience and the internationalisation speed of retailers. Int Mark Rev 31(6):601-620

Moray N, Clarysse B (2005) Institutional change and resource endowments to science-based entrepreneurial firms. Res Policy 34(7):1010-1027

Mosey S, Wright M (2007) From human capital to social capital: a longitudinal study of technologybased academic entrepreneurs. Entrep Theory Pract 31(6):909-935

Mumford MD, Zaccaro SJ, Connelly MS, Marks MA (2000) Leadership skills: conclusions and future directions. Leadersh Q 11(1):155-170

Munari F, Toschi L (2011) Do venture capitalists have a bias against investment in academic spin-offs? Evidence from the micro-and nanotechnology sector in the UK. Ind Corp Chang 20(2):397-432

Mustar P, Renault M, Colombo MG, Piva E, Fontes M, Lockett A, Moray N (2006) Conceptualising the heterogeneity of research-based spin-offs: a multi-dimensional taxonomy. Res Policy 35(2):289-308

Musteen M, Francis J, Datta DK (2010) The influence of international networks on internationalization speed and performance: a study of Czech SMEs. J World Bus 45(3):197-205

Naudé W, Rossouw S (2010) Early international entrepreneurship in China: extent and determinants. J Int Entrep 8(1):87-111

Nelson D, Cooper CL (2007) Positive organizational behavior: accentuating the positive at work. Sage, Thousand Oaks, CA

Nielsen S (2010) Top management team internationalization and firm performance. Manag Int Rev 50(2):185-206 
Nielsen K (2015) Human capital and new venture performance: the industry choice and performance of academic entrepreneurs. J Technol Transf 40(3):453-474

Nowiński W, Rialp A (2013) Drivers and strategies of international new ventures from a Central European transition economy. J East Eur Manag Stud 18(2):191-231

Obschonka M, Silbereisen RK, Schmitt-Rodermund E (2010) Entrepreneurial intention as developmental outcome. J Vocat Behav 77(1):63-72

Obschonka M, Moeller J, Goethner M (2019) Entrepreneurial passion and personality: the case of academic entrepreneurship. Front Psychol 9(2697):1-15

O'Gorman C, Evers N (2011) Network intermediaries in the internationalisation of new firms in peripheral regions. Int Mark Rev 28(4):340-364

Onkelinx J, Manolova TS, Edelman LF (2016) The human factor: Investments in employee human capital, productivity, and SME internationalization. J Int Manag 22(4):351-364

O'Shea RP, Chugh H, Allen TJ (2008) Determinants and consequences of university spinoff activity: a conceptual framework. J Technol Transf 33(6):653-666

Osland JS, BirdA, Mendenhall M, Osland A (2006) Developing global leadership capabilities and global mindset: a review. In K. G.K. Stahl \& I. Björkman. Handbook of Research in International Human Resource Management 11:197-222

Oviatt BM, McDougall PP (1994) Toward a theory of international new ventures. J Int Bus Stud 25(1):45-64

Oviatt BM, McDougall PP (1995) Global start-ups: entrepreneurs on a worldwide stage. Acad Manag Perspect 9(2):30-43

Oviatt BM, McDougall PP (1997) Challenges for internationalization process theory: the case of international new ventures. Manag Int Rev 37(2):85-99

Oviatt BM, McDougall PP (2005) Defining international entrepreneurship and modeling the speed of internationalization. Entrep Theory Pract 29(5):537-553

Oviatt BM, McDougall PP (2007) International entrepreneurship. Edward Elgar Publishing

Ozgen E, Baron RA (2007) Social sources of information in opportunity recognition: effects of mentors, industry networks, and professional forums. J Bus Ventur 22(2):174-192

Parente R, Feola R, Cucino V, Catolino G (2015) Visibility and reputation of new entrepreneurial projects from academia: the role of start-up competitions. J Knowl Econ 6(3):551-567

Parker S (1998) Enhancing role-breath self-efficacy: the roles of job enrichment and other organizational interventions. J Appl Psychol 83(6):835-852

Peces Prieto MDC, Trillo Holgado MA (2019) The influence of relational capital and networking on the internationalization of the university spin-off. Intangible Capital 15(1):22-37

Peiris IK, Akoorie ME, Sinha P (2012) International entrepreneurship: a critical analysis of studies in the past two decades and future directions for research. J Int Entrep 10(4):279-324

Peng MW (2001) The resource-based view and international business. J Manag 27(6):803-829

Peterson C (2006) A primer in positive psychology, Oxford university press

Pettersen IB, Tobiassen AE (2012) Are born globals really born globals? The case of academic spin-offs with long development periods. J Int Entrep 10(2):117-141

Perez MP, Sánchez AM (2003) The development of university spin-offs: early dynamics of technology transfer and networking. Technovation 23(10):823-831

Pathak S, Goltz S (2021) An emotional intelligence model of entrepreneurial coping strategies. Int J Entrep Behav Res 27(4):911-943

Pigatto G, Pigatto, GAS, Satolo EG, Dos Santos Negreti A (2019) The importance and the adaptation of internal resources as a competitive advantage for the internationalization of food companies: an analysis of Brazilian companies. Grey Systems: Theory and Application.

Pirnay F, Surlemont B, Niemvo F (2003) Toward a typology of university spin-offs. Small Bus Econ 21(4):355-369

Pinkwart A, Proksch D (2014) The internationalization behavior of German high-tech start-ups: an empirical analysis of key resources. Thunderbird Int Bus Rev 56(1):43-53

Powers JB, McDougall PP (2005) University start-up formation and technology licensing with firms that go public: a resource-based view of academic entrepreneurship. J Bus Ventur 20(3):291-311

Prodan I, Drnovsek M (2010) Conceptualizing academic-entrepreneurial intentions: an empirical test. Technovation 30(5-6):332-347

Rahman M, Mendy J (2018) Evaluating people-related resilience and non-resilience barriers of SMEs' internationalisation. Int J Organ Anal 27(2):225-240 
Rasmussan ES, Madsen TK, Evangelista F (2001) The founding of the born global company in Denmark and Australia: sensemaking and networking. Asia Pac J Mark Logist 13(3):75-107

Rasmussen E (2011) Understanding academic entrepreneurship: exploring the emergence of university spin-off ventures using process theories. Int Small Bus J 29(5):448-471

Ratajczak-Mrozek M (2017) Network embeddedness: examining the effect on business performance and internationalization. Springer

Rhinesmith SH (1996) A manager's guide to globalization, Mc Graw Hill.

Ripolles-Melia M, Menguzzato-Boulard M, Sanchez-Peinado L (2007) Entrepreneurial orientation and international commitment. J Int Entrep 5(3):65-83

Rivas JL, Hamori M, Mayo M (2009) Board composition and firm internationalization. Acad Manag Proc $1: 1-6$

Roberts EB, Senturia TA (1996) Globalizing the emerging high-technology company. Ind Mark Manage 25(6):491-506

Roberts DE, Malone E (1996) Policies and structures for spinning off new companies from research and development organizations. R\&D Management 26(1):17-48

Ruzzier M, Antončič B, Konečnik M (2006) The resource-based approach to the internationalisation of SMEs: differences in resource bundles between internationalised and non-internationalised companies. Zagreb Int Rev Econ Bus 9(2):95-116

Saetre AS, Wiggins J, Atkinson OT, Atkinson BKE (2009) University spin-offs as technology transfer: a comparative study among Norway, the United States, and Sweden. Comp Technol Transf Soc 7(2):115-145

Sahaym A (2013) Born with a silver spoon of legitimacy but struggling for identity? The paradox of emerging spin-offs in a new sector. J Bus Res 66(11):2210-2217

Sambharya RB (1996) Foreign experience of top management teams and international diversification strategies of US multinational corporations. Strateg Manag J 17(9):739-746

Sánchez LPC, Castro CB, Periñán MDMV (2015) Integrating the board's resources to achieve a firm's internationalisation. Academia Revista Latinoamericana De Administración 28(3):332-358

Sapienza HJ, Autio E, George G, Zahra SA (2006) A capabilities perspective on the effects of early internationalization on firm survival and growth. Acad Manag Rev 31(4):914-933

Seguí-Mas E, Oltra V, Tormo-Carbó G, Sarrión-Viñes F (2018) Rowing against the wind: how do times of austerity shape academic entrepreneurship in unfriendly environments? Int Entrep Manag J 14(3):725-766

Scheier MF, Carver CS (1985) Optimism, coping, and health: assessment and implications of generalized outcome expectancies. Health Psychol 4(3):219-247

Schweizer R, Vahlne JE, Johanson J (2010) Internationalization as an entrepreneurial process. J Int Entrep 8(4):343-370

Sekliuckiene J (2017) Factors leading to early internationalization in emerging Central and Eastern European economies. Eur Bus Rev 29(5):219-242

Seligman ME, Csikszentmihalyi M (2000) Special issue: positive psychology. Am Psychol 55(1):5-14

Senik ZC, Isa RM, Sham RM, Ayob AH (2014) A model for understanding SMEs internationalization in emerging economies. Jurnal Pengurusan (UKM Journal of Management) 41:25-42

Shaffer MA, Harrison DA, Gilley KM (1999) Dimensions, determinants, and differences in the expatriate adjustment process. J Int Bus Stud 30(3):557-581

Shaffer MA, Harrison DA, Gregersen H, Black JS, Ferzandi LA (2006) You can take it with you: individual differences and expatriate effectiveness. J Appl Psychol 91(1):109-155

Shane S, Venkataraman S (2000) The promise of entrepreneurship as a field of research. Acad Manag Rev 25(1):217-226

Shane SA (2003) A general theory of entrepreneurship: the individual-opportunity nexus, Edward Elgar Publishing.

Shane SA (2004) Academic entrepreneurship: university spinoffs and wealth creation, Edward Elgar Publishing.

Sharma DD, Blomstermo A (2003) The internationalization process of born globals: a network view. Int Bus Rev 12(6):739-753

Shinnar RS, Hsu DK, Powell BC (2014) Self-efficacy, entrepreneurial intentions, and gender: assessing the impact of entrepreneurship education longitudinally. Int J Manag Educ 12(3):561-570

Shirokova G, McDougall-Covin P (2012) The role of social networks and institutions in the internationalization of Russian entrepreneurial firms: do they matter? J Int Entrep 10(3):177-199 
Smith KG, Collins CJ, Clark KD (2005) Existing knowledge, knowledge creation capability, and the rate of new product introduction in high-technology firms. Acad Manag J 48(2):346-357

Snyder CR, Sympson S, Ybasco F, Borders T, Babyak M, Higgins R (1996) Development and validation of the state hope scale. J Pers Soc Psychol 70(2):321-335

Sousa-Ginel E, Franco-Leal N, Camelo-Ordaz C (2017) The influence of networks on the knowledge conversion capability of academic spin-offs. Ind Corp Chang 26(6):1125-1144

Styles C, Seymour RG (2006) Opportunities for marketing researchers in international entrepreneurship. Int Mark Rev 23(2):126-145

Sullivan D (1994) Measuring the degree of internationalization of a firm. J Int Bus Stud 25(2):325-342

Taheri M, Van Geenhuizen M (2011) How human capital and social networks may influence the patterns of international learning among academic spin-off firms. Pap Reg Sci 90(2):287-311

Teixeira AA, Coimbra C (2014) The determinants of the internationalization speed of Portuguese university spin-offs: an empirical investigation. J Int Entrep 12(3):270-308

Thai MTT, Chong LC (2008) Born-global: the case of four Vietnamese SMEs. J Int Entrep 6(2):72-100

Tihanyi L, Ellstrand AE, Daily CM, Dalton DR (2000) Composition of the top management team and firm international diversification. J Manag 26(6):1157-1177

Turcan RV (2013) International new venture legitimation: an exploratory study. Adm Sci 3(4):237-265

Van Geenhuizen M, Soetanto DP (2009) Academic spin-offs at different ages: a case study in search of key obstacles to growth. Technovation 29(10):671-681

Van Geenhuizen M, Ye Q, Au-Yong-Oliveira M (2015) University spin-off firms? internationalization: importance of skills. In ERSA conference papers (No. ersa15p644). European Regional Science Association.

Vapola TJ (2011) The laws of attraction: what attracts innovative start-up firms to partnerships with global MNCs? J Int Entrep 9(1):39-61

Villanueva-Flores M, Diaz-Fernandez M, Hernandez-Roque D, Van Engen M (2021) Psychological capital and entrepreneurship: gender differences. Gend Manag: an Int J 36(3):410-429

Visintin F, Pittino D (2014) Founding team composition and early performance of university-based spinoff companies. Technovation 34(1):31-43

Vissak T (2007) The emergence and success factors of fast internationalizers: four cases from Estonia. J East-West Bus 13(1):11-33

Vohora A, Wright M, Lockett A (2004) Critical junctures in the development of university high-tech spinout companies. Res Policy 33(1):147-175

Volonté C, Gantenbein P (2016) Directors' human capital, firm strategy, and firm performance. J Manage Governance 20(1):115-145

Wach K, Głodowska A (2021) How do demographics and basic traits of an entrepreneur impact the internationalization of firms? Oeconomia Copernicana 12(2):399-424

Wagnild GM, Young HM (1993) Development and psychometric evaluation of the resiliency scale. J Nurs Manag 1:165-178

Wang Y, Tsai CH, Lin DD, Enkhbuyant O, Cai J (2019) Effects of human, relational, and psychological capitals on new venture performance. Front Psychol 10(1071):1-10

Wasowska A (2019) Social-cognitive antecedents of new venture internationalization. Balt J Manag 14(3):462-479

Weerawardena J, Mort GS, Liesch PW, Knight G (2007) Conceptualizing accelerated internationalization in the born global firm: a dynamic capabilities perspective. J World Bus 42(3):294-306

Welch CL, Welch LS (2004) Broadening the concept of international entrepreneurship: internationalisation, networks and politics. J Int Entrep 2(3):217-237

Wright TA (2003) Positive organizational behavior: an idea whose time has truly come. J Organ Behav 24(4):437-442

Wright RW, Dana LP (2003) Changing paradigms of international entrepreneurship strategy. J Int Entrep 1(1):135-152

Wright M, Birley S, Mosey S (2004) Entrepreneurship and university technology transfer. J Technol Transf 29(3-4):235-246

Wright M, Lockett A, Clarysse B, Binks M (2006) University spin-out companies and venture capital. Res Policy 35(4):481-501

Wright TA, Cropanzano R (2007) The happy/productive worker thesis revisited. In Martocchio, J. (Ed.), Research in Personnel and Human Resources Management 26(Amsterdam):269-313. 
Wright M, Westhead P, Ucbasaran D (2007) Internationalization of small and medium sized enterprises (SMEs) and international entrepreneurship: a critique and policy implications. Reg Stud 41(7):1013-1029

Yang S, Kher R, Newbert SL (2020) What signals matter for social startups? It depends: the influence of gender role congruity on social impact accelerator selection decisions. J Bus Ventur 35(2):105-932

Yeoh PL (2004) International learning: antecedents and performance implications among newly internationalizing companies in an exporting context. Int Mark Rev 21(4/5):511-535

Yeung AK, Ready DA (1995) Developing leadership capabilities of global corporations: a comparative study in eight nations. Hum Resour Manage 34(4):529-547

Zaheer S, Mosakowski E (1997) The dynamics of the liability of foreignness: a global study of survival in financial services. Strateg Manag J 18(6):439-463

Zahra SA, George G (2002a) International entrepreneurship: the current status of the field and future research agenda. Strategic entrepreneurship: creating a new mindset. In M. Hitt, R. Duane, S. Camp and D. Sexton (Eds.) Wiley Blackell:255-288.

Zahra AS, George G (2002b) International entrepreneurship: the current status of the field and future research agenda. In: Hitt MA, Ireland RD, Camp SM, Sexton DL (eds) Strategic entrepreneurship: creating a new mindset. Blackwell, Oxford, pp 255-288

Zahra SA, Matherne BP, Carleton JM (2003) Technological resource leveraging and the internationalization of new ventures. J Int Entrep 1(2):163-186

Zahra SA, Korri JS, Yu J (2005) Cognition and international entrepreneurship: implications for research on international opportunity recognition and exploitation. Int Bus Rev 14(2):129-146

Zhao H, Seibert SE, Hills GE (2005) The mediating role of self-efficacy in the development of entrepreneurial intentions. J Appl Psychol 90(6):1265-1272

Zhao J, Wei G, Chen KH, Yien JM (2020) Psychological Capital and university students' entrepreneurial intention in china: mediation effect of entrepreneurial capitals. Front Psychol 10(2984):1-11

Zhou L, Wu WP, Luo X (2007) Internationalization and the performance of born-global SMEs: the mediating role of social networks. J Int Bus Stud 38(4):673-690

Zou X, Morris MW, Benet-Martínez V (2008) Identity motives and cultural priming: Cultural (dis) identification in assimilative and contrastive responses. J Exp Soc Psychol 44(4):1151-1159

Zou H, Chen X, Lam LWR, Liu X (2016) Psychological capital and conflict management in the entrepreneur-venture capitalist relationship in China: the entrepreneur perspective. Int Small Bus $\mathrm{J}$ 34(4):446-467

Zou B, Guo J, Guo F, Shi Y, Li Y (2019) Who am I? The influence of social identification on academic entrepreneurs' role conflict. Int Entrep Manag J 15(2):363-384

Publisher's Note Springer Nature remains neutral with regard to jurisdictional claims in published maps and institutional affiliations.

\section{Authors and Affiliations}

\section{Mariluz Fernández-Alles ${ }^{1}$ (D) Dara Hernández-Roque ${ }^{1}$. Mercedes Villanueva-Flores ${ }^{1}$ (D) - Mirta Díaz-Fernández ${ }^{2}$ (D)}

Dara Hernández-Roque

dara.hernandez@uca.es

Mercedes Villanueva-Flores

mercedes.villanueva@uca.es

Mirta Díaz-Fernández

mdiafer@upo.es

1 Business Administration Department, Cadiz University, Cádiz, Spain

2 Businesss Administration and Marketing Department, Pablo de Olavide University, Seville, Spain 